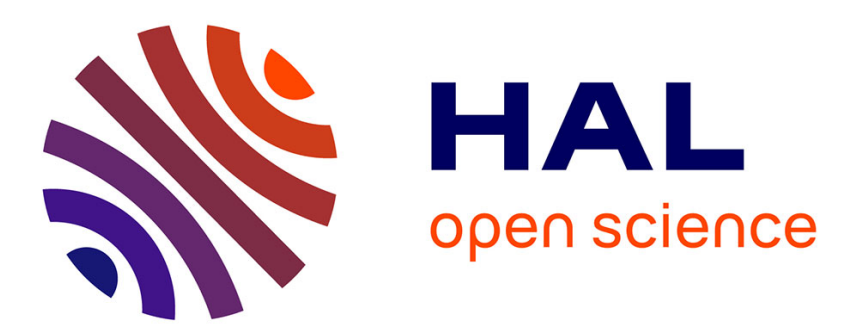

\title{
A review of 20 years (1999-2019) of Turkish-French collaboration in marine geoscience research in the Sea of Marmara
}

\author{
Louis Géli, Pierre Henry, M. Namik Namik Çağatay
}

\section{- To cite this version:}

Louis Géli, Pierre Henry, M. Namik Namik Çağatay. A review of 20 years (1999-2019) of TurkishFrench collaboration in marine geoscience research in the Sea of Marmara. Mediterranean Geoscience Reviews, 2021, 3 (1), pp.3-27. 10.1007/s42990-021-00055-8 . hal-03463319v2

\section{HAL Id: hal-03463319 \\ https://hal.science/hal-03463319v2}

Submitted on 5 Dec 2021

HAL is a multi-disciplinary open access archive for the deposit and dissemination of scientific research documents, whether they are published or not. The documents may come from teaching and research institutions in France or abroad, or from public or private research centers.
L'archive ouverte pluridisciplinaire HAL, est destinée au dépôt et à la diffusion de documents scientifiques de niveau recherche, publiés ou non, émanant des établissements d'enseignement et de recherche français ou étrangers, des laboratoires publics ou privés. 


\title{
A review of 20 years (1999-2019) of Turkish-French collaboration in marine geoscience research in the Sea of Marmara
}

\author{
Louis Géli1Đ ${ }^{1}$ Pierre Henry² $\cdot$ M. Namik Çağatay ${ }^{3}$ \\ $\bowtie$ Louis Géli louis.geli@ifremer.fr \\ 1 Unité de Recherche Géosciences Marines, Ifremer, 29280 Plouzané, France \\ 2 Aix Marseille Univ, CNRS, IRD, INRAE, Coll France, CEREGE, Aix-en-Provence, France \\ 3 Maden Fakültesi, İstanbul Teknik Universitesi,Jeoloji Bölümü, Ayazağa, 34469 İstanbul, Turkey
}

Received: 7 January 2021 / Revised: 17 March 2021 / Accepted: 19 March 2021 / Published online: 4 May 2021

\begin{abstract}
This paper retraces the history and main achievements of the ongoing Turkish-French collaboration in marine geoscience research in the Sea of Marmara, which was initiated in the aftermath of the 1999, Izmit and Duzce earthquakes. The collaboration resulted in nine large oceanographic cruises along with six recovery operations involving diverse vessels, and in the participation in two major EU-funded programmes (ESONET-NoE and MARSITE) and to one bilateral project, e.g. the MAREGAMI Project, co-funded by TUBITAK and ANR (the Turkish and French national funding agencies for research, respectively). In this paper, we review the major scientific contributions on the tectonic evolution of the North-Anatolian Fault in the Marmara Region; on the relationships between faulting, seismicity, fluids and ecosystems; and on paleo-seismology and paleo-oceanography in the Sea of Marmara.
\end{abstract}

\section{Introduction: the situation beforethe1999 earthquakes}

During the second half of the XXth century, after Ketin (1968) first established the relations between the general tectonic features and earthquake activity in Turkey, the North Anatolian Fault Zone received considerable attention (e.g. Şengör 1979; Barka 1981). The westward migration of earthquake ruptures (starting from the 1939 Erzincan earth- quake in the easternmost end of the NAF) had already been established in the late 1970's (e.g. Töksöz et al. 1979) and in 1997, when Stein, Barka and Dieterich estimated "a $12 \%$ probability for a large event $(M>6.7)$ to occur south of the major western port city of Izmit in the next 30 years" (Stein et al. 1997), it was nothing but a premonition. What a pos- teriori became an astonishingly successful prediction when the earthquake struck in Izmit 2 years later, Barka (1999) was based on the detailed mapping of surface slip and fault geometry of the North Anatolian Fault, that resulted from
3 decades of continuous geophysical and geological onshore investigations (e.g. Şengör et al. 1985; Barka 1992, 1996; Barka and Kadinsky-Cade 1988, and references therein). On-land studies also benefited from spectacular advances in space geodesy that revolutionized earth sciences in the 1990's (e.g. Le Pichon et al. 1995; Reilinger et al. 1997). In contrast, by the end of the century, there was a tremendous gap in knowledge between the onshore and offshore domains in the Marmara Region. Consequently, the question of the westward propagation of the NorthAnatolian Fault into the Sea of Marmara was entirely open.

Indeed, prior to 1995, the knowledge of the Marmara sea- floor was essentially based on: hydrographic maps from the Office of Navigation, Hydrography and Oceanography of Turkey (SHOD); sparse borehole data from the oil industry; and a few, widely spaced seismic reflection lines, acquired by the Turkish Petroleum Corporation (TPAO), by Mara- thon Oil, and by the Institute of Marine Sciences and Tech- nology (IMST) of Dokuz Eyul University (DEU) in Izmir (e.g. Smith et al. 1995; Ergün and Özel 1995; Özel 1992; Wong et al. 1995; see also review in Palabiyik et al. 2020; Görür et al. (1997) and references therein). In 1995, the research vessel (R/V) Piri Reis of IMST acquired $3300 \mathrm{~km}$ of single channel, seismic profiles and $1000 \mathrm{~km}$ of deep-towed boomer profiles. These data were used to draw-up a bathymetric map revealing three deep (> $1000 \mathrm{~m}$ ) basins "bounded by and internally cut by numerous steeply, dip- ping faults" (Aksu et al. 1999). In 1997, (the Scientific and 
Technical Research Council of Turkey (TUBITAK) initiated the Turkish Marine Programme, coordinated by Naci Görürand funded by the State Planning Organization of Turkey (DPT). The programme had access to the research vessels of Mineral Research and Exploration Directorate of Turkey (MTA) and Turkish Naval Forces-Office of Navigation, Hydrography and Oceanography (SHOD). The programme acquired $2200 \mathrm{~km}$ of multi-channel seismic reflection lines, with MTA's $R / V$ Sismik-1 (see review in Imren et al. 2001, p. 145). Two different groups, from Istanbul Technical University (ITU) and from the University of Cambridge, respectively, proposed two different tectonic interpretations, reflecting the contrasting views that prevailed at that time, based on land observations. Okay et al. (1999) supported Pinar's (1943) early idea of a single through-going fault, later called the "Main Marmara Fault" (MMF; Le Pichon et al. 2001), bisecting the Gulf of Izmit and the three Mar-mara deeps, in agreement with the view of Şengör (1979) and Şengör et al. (1985). In contrast, Parke et al. (1999) sup- ported the view depicting the Sea of Marmara as a rift basin with en echelon faulting and little or no strike-slip fault in the central Marmara Sea (e.g. Armijo et al. 1999). In Febru- ary 1999, multibeam bathymetric data were collected and sediment pore fluids were sampled from the deep Marmara basins during R/V Meteor cruise 44 (Halbach et al. 2000), identifying methane anomalies, suggesting the existence of an active hydrological system associated with the submarine fault system.

\section{In the aftermath of the 1999earthquakes: the NATO conference on May 14-17th, 2000}

The catastrophic death toll (>20,000 victims) of the Izmit and Düzce earthquakes in August and November 1999 created an immense worldwide shock and emotion. Meanwhile, an earthquake hit Athens on September 7th, 1999, causing 143 deaths. These three events compelled international collaboration for future earthquake risk assessment in the region. A first conference was held at ITU in 1999, during which different strategies were presented to fill the knowl- edge gap in the Sea of Marmara (e.g. Le Pichon et al. 1999). A second conference was held in Istanbul on 14-17 May 2000 as a NATO international Advanced Research Seminar with the primary objective of providing a platform for open discussions and for fostering international collaborative studies. Coordinated by TUBITAK, the NATO seminar was attended by 83 scientists from Turkey, France, Italy, USA, UK, Japan, Germany and Greece (Görür et al. 2002).

Earthquakes were known to have occurred in the Sea of Marmara near Istanbul in the past (e.g. Ambraseys and Finkel 1995). The question that was on everyone's mind was: when and where will the next earthquake strike? As a corollary: how will the stress be transferred in the submarine domain, between the 1999 rupture in Izmit and the 1912 rupture in Saros? More generally, from a geodynamic point of view, the major scientific issue was to understand how the North-Anatolian Fault, a major strike-slip plate boundary, propagates into the Aegean extensional system. Different views - or different groups of ideas-having different implications for earthquake hazard assessment were discussed during the NATO seminar. The first group considered the prevailing role of extension (Parke et al. 1999) and viewed the Marmara Trough as a pull-apart basin with oblique extension (e.g. Barka and Kadinsky-Cadé 1988; Armijo et al. 1999; Hubert-Ferrari et al. 2000). The second considered the prevailing role of strain localization along a transform, through-going, strike-slip fault following a small circle corresponding to the relative motion between the Eur- asian and Anatolian plates (e.g. Le Pichon et al. 2001). And the third group considered the Marmara Area as "a negative flower structure controlled by a single master fault", identi- fied as the northern branch of the North Anatolian Fault Zone (e.g. Okay et al. 1999; Alpar and Yaltirak 2000).

After the NATO seminar, a number of research programmes in marine geoscience research were set up, through bi-lateral and tri-lateral collaborations between Turkey and a large number of foreign countries, including the United States, Italy, Germany, Japan and France. The Turkish-French cooperation programme, initiated by Xavier Le Pichon and Çelal Şengör, was coordinated by INSU and TÜBITAK. It started 3 months later, once Xavier Le Pichon had obtained the funds for the mapping cruise of R/V Le Suroit (12 September-3 October 2000) from the ECHO division of the European Community.

\section{ActionsundertheTurkish-French collaboration in marine research since 1999}

The collaboration resulted in nine large oceanographic cruises and six recovery operations involving diverse vessels since 1999. All cruises included scientists from other countries (e.g. Germany, Italy, USA, Spain, China, etc.). The collaboration largely benefited from the assistance of the Turkish Coast-Guard Command (Sahil Güvenlik) and was supported by EU-funded programmes, which in turn allowed for access to marine facilities at different institutions in Europe. Most particularly, the research vessel Urania, from the Italian National Research Council, was used on many occasions within the framework of EU supported projects, e.g. ESONET-NoE and MARSITE (see Gasperini et al. 2018 and cruise reports in http://www.ismar.cnr.it/prodotti/repor ts-campagne). The collaboration also benefited from the 
knowledge gained through other bi-lateral programmes, such as between Turkey and the USA. For instance, the TAMAM cruise on R/V Piri Reis in 2010 (co-P.I.s Çifci from Dokuz Eylül University and Steckler, from Lamont Doherty Earth Observatory) offered unique opportunities for scientific exchanges within the marine geoscience community.

The cruises that were conducted on French vessels were given a DOI (Digital Object Identifier), providing immediate access to the associated publications. The full list is detailed in Table 1. A brief, chronological summary is provided here below:

- 2000: The MARMARA cruise (Chief scientists: Le Pichon, Sengör, Demirbağ) on $R / V$ Le Suroît provided the first, detailed integral mapping coverage of the Marmara seafloor. In addition to high-resolution, multibeam bathymetry and imagery data (grid-mesh size of $38 \mathrm{~m}$ ), deep-towed side scan sonar data were collected along with shallow seismic data using a surface sparker source and a deep-towed seismic source (e.g. Rangin et al. 2001; Le Pichon et al. 2001; Imren et al. 2001; Demirbağ et al. 2003). See more and publication list on: https://doi.org/ 10.17600/20100.

- 2001: The SEISMARMARA cruise on R/V Nadir (Chief Scientists Hirn, Singh \& Taymaz), was conducted with the support of R/V Simik-1 of MTA and divided into two legs. Leg I (P.I. Hirn \& Taymaz) resulted in the acquisition of $4000 \mathrm{~km}$ of large penetration, reflection seismic data along with refraction seismic data (OBS and onshore stations), to determine the deep (>10 km) structure below the Sea of Marmara (e.g. Laigle et al. 2008; Bécel et al. 2009, 2010; Bayrakci et al. 2013). Leg II (P. I. Singh \& Taymaz) provided high-resolution seismic imaging of the Eastern Sea of Marmara (Çınarcık Basin and its margins) along 80 , densely spaced $(0.5-0.9 \mathrm{~km})$ lines (e.g. Carton et al. 2007). See more and publication list on: https://doi.org/10.17600/1080050.

- 2001: The MD 123-MARMACORE cruise on $R / V$ Marion Dufresne within the GEOSCIENCE 1 project (coordinated by Turon), provided a large variety of long, sediment cores, establishing the base for all future paleo- seismological and paleoceanographic studies in the Sea of Marmara (Chiefs Scientists: Mercier de Lépinay, Labeyrie, Çağatay). See publication list on: https://doi. org/10.17600/1200050.

- 2002: The MARMARASCARPS (P.I.s Armijo, Mala- vieille \& Çağatay) on $R / V$ L'Atalante with ROV Victor provided fine-scale mapping of active fault scarps along with 3.5 $\mathrm{kHz}$ sediment profiling and long cores for paleo- seismological studies (e.g. Armijo et al. 2005). ROV dives also provided the first visual observations of cold seeps along the fault (e.g. Zitter et al. 2008). See publication list and more on: https://doi.org/10.17600/2010140.

- 2004: The MARMARA VT 67 \& MARMARA VT68 cruises on $R / V$ Marion-Dufresne (Chief Scientists: Henry, Delaygue \& Çağatay for VT67 and Lericolais for VT68), provided very long cores for advanced studies in paleoseismology paleoceanography. See publication list on https://doi.org/10.17600/4200080 (VT-67) and (VT68) 10.17600/4200120.

- 2007: The MARNAUT Cruise conducted on $R / V$ L'Atalante with the Nautile submersible (Chief Scientists: Henry; Şengör; Çağatay), provided the first visual observations of gas seeps and in situ gas samples, leading to the characterization of fluid emissions (e.g. Tryon et al. 2010) and to the evidence that the North Anatolian Fault was cutting through a gas and oil system related to the Thrace Basin oil field (Bourry et al. 2009). See more in $\S$ V.2 and publication list on: https://doi.org/10.17600/7010070.

- 2009: The MARMESONET Cruises on R/V Le Suroit (chief scientists: Géli; Henry; Çağatay) represented the Demonstration Mission aiming at preparing future deployments of multi-parameter, permanent seafloor observato- ries on the Marmara seafloor within the European Seafloor Observatory Network of Excellence (ESONET-NoE). It was one of the first worldwide acoustic surveys of the water column, using multibeam echosounder. See more in $\S$ V.3 and publication list on: https://doi.org/10.17600/9020040.

- 2010: The PIRMARMARA Cruise (P. I.s Çifçi and Marsset) on R/V Piri Reis, provided long-offset, 2D seismic data from the deep Marmara Trough that successfully completed the coverage obtained during the Marmesonet cruise (e.g. Şarıtaş 2018). Additional profiles from the southern shelf were also acquired for further investigations on the Messinian event in the Sea of Marmara.

- 2014: The MARSITECRUISE on $R / V$ Pourquoi pas? with the ROV Victor-6000 (P. I.s Géli, Ruffine, Henry and Çağatay) was part of the marine operations conducted within the MARSITE Project (P.I. Nurçan Özel). During leg 1 , seafloor instruments were deployed. During leg 2, sediment, water and gas samples were taken using ROV Victor-6000 (e.g. Ruffine et al. 2018a, b, c). During leg 3, additional $3.5 \mathrm{kHz}$ and sediment cores were acquired at key sites for paleo-seismological studies. See more in $\S$ IV.2 and in $\S$ V.4, and publications list on: https://doi.org/ $10.17600 / 14000500$. 
Table 1 List of cruises conducted in the Sea of Marmara within the Turkish-French collaboration in marine geoscience since

\begin{tabular}{|c|c|c|}
\hline 1999 Cruise & & Summary of measurements \\
\hline Name & Tharmara & Bathymetry and reflectivity with EIVIJण0 echosounder \\
\hline Year & 2000 & $\begin{array}{l}\text { Single-channel seismics using surface source (sparker) } \\
\text { Deep-tow sidescan sonar (SAR) }\end{array}$ \\
\hline Vessel & R/V Le Suroit (Ifremer) & Deep-tow High resolution seismics (PASISAR) \\
\hline Chief scientists & Le Pichon, Şengör Demirbağ & \\
\hline Doi & $10.17600 / 20100$ & \\
\hline Programme & Cnrs/Tubitak Coll. & \\
\hline Funding Source & EU (ECHO Programme) & \\
\hline Name & SEISMARMARA & $4000 \mathrm{~km}$ of MCS profiles \\
\hline Year & 2001 & $\begin{array}{l}\text { Coordination with on-land seismological networks } \\
\text { (permanent complemented by } 30 \text { temporary }\end{array}$ \\
\hline Vessel & R/V Nadir (Ifremer) +support of MTA Sismik-1 & stations to record off-shore seismic shots) \\
\hline Chief scientists & Hirn, Singh, Taymaz & Leg 1 (Hirn) \\
\hline $\begin{array}{l}\text { Doi } \\
\text { Programme } \\
\text { Funding Source }\end{array}$ & $\begin{array}{l}\text { 10.17600/1080050 } \\
\text { Cnrs/Tubitak collab. }\end{array}$ & $\begin{array}{l}\text { seismic soundings: } 8100 \text { cu-inch; } 12 \text { air-gun array on } \\
\text { single bubble mode } \\
4 \mathrm{E}-\mathrm{W} \text { lines and } 30 \text { cross-lines in the whole Marmara } \\
\text { Trough } \\
\text { Deployment of } 37 \text { OBSs with MTA Sismik-1 for } \\
\text { refraction seismics and seismic tomography (OBSs } \\
\text { from IRD, INSU, University of Hokkaïdo). } \\
\text { Leg } 2 \text { (Singh) } \\
2900 \text { cu-inch source allowing denser shot spacing } \\
80 \text { dip-lines at } 0.6-0.9 \text { km spacing }(0.6-0.9 \mathrm{~km} \text { ) in the } \\
\text { Cinarcik basin and its margins }\end{array}$ \\
\hline Support vessels & MTA Sismik-1 & OBS recovery \\
\hline & Turkish coast guard & Permanent operational assistance \\
\hline Name & MD-123 MARMARACORE-1 & Piston-corer (of the giant CALYPSO-type) core sam- \\
\hline Year & 2001 & ples \\
\hline Vessel & Marion Dufresne (IPEV) & Gravity core samples \\
\hline Chief scientists & Mercier de Lépinay, Labeyrie, Çagatay & \\
\hline Doi & $10.17600 / 1200050$ & \\
\hline Programme & $\begin{array}{l}\text { GEOSCIENCE } 1 \text { Project (coord JL Turon) and } \\
\text { European projects POP and GEOMOUND }\end{array}$ & \\
\hline Funding Source & EU & \\
\hline Name & MARMARASCARPS & Micro-bathymetric surveys with Victor and Seabat \\
\hline $\begin{array}{l}\text { Year } \\
\text { Vessel }\end{array}$ & $\begin{array}{l}2002 \\
\text { Pourquoi pas ? / ROV VICTOR } 2000 \text { (Ifremer) }\end{array}$ & $\begin{array}{l}8101.6 \text { dives, } 300 \mathrm{~km} \text { surveyed } \\
\text { Visual exploration of faults, core samples by Victor and } \\
\text { rock samples }\end{array}$ \\
\hline Chief scientists & Armijo, Malavieille, Çagatay & $\begin{array}{l}6 \text { dives, } 80 \mathrm{~km} \text { of exploration ( } 231 \text { SVHS tapes; } 45 \\
\text { Betacam), } 94 \text { Victor cores and } 13 \text { rock samples taken }\end{array}$ \\
\hline $\begin{array}{l}\text { Doi } \\
\text { Programme }\end{array}$ & $\begin{array}{l}\text { 10.17600/2,010,140 } \\
\text { Cnrs/Tubitak collab }\end{array}$ & $\begin{array}{l}\text { Transit xwith } 3.5 \mathrm{kHz} \text { profile acquisition, } 10 \text { trips, } 600 \\
\mathrm{~km} \text { of } 3.5 \mathrm{kHz} \text { at } 6 \text { knots }\end{array}$ \\
\hline Funding Source & & Kullenberg core samples - 8 cores taken \\
\hline Support vessels & Turkish coast guard & Permanent operational assistance \\
\hline Name & $\begin{array}{l}\text { MARMARA-VT } 67 \\
\text { MARMARA-VT } 68\end{array}$ & $\begin{array}{l}\text { MARMARA-VT67 (Henry, Delaygue) }-03 / 05 \text { to } \\
07 / 05 / 2004 \\
\text { Sediment sampling }\end{array}$ \\
\hline- & 2004 & 13 long Calypso cores \\
\hline Vessel & Marion Dufresne (IPEV) & 3 Gravity cores \\
\hline Chief scientists & Lericolais, Henry, Delaygue & $3.5 \mathrm{kHz}$ (sediment penetrator) profiles \\
\hline Doi & $10.17600 / 4200080$ and $10.17600 / 4200120$ & Hydrological stations with water bottle sampling \\
\hline $\begin{array}{l}\text { Programme } \\
\text { Funding Source }\end{array}$ & $\begin{array}{l}\text { ACI-FNS hazards and global change project/ } \\
\text { ASSEMBLAGE Project } \\
\text { EU }\end{array}$ & $\begin{array}{l}\text { MARMARA-VT } 68 \text { (Lericolais) } \\
\text { Sediment sampling from long sediment cores } \\
\text { Extraction of interstitial fluids for geochemical and } \\
\text { isotopic analysis (e.g. } \mathrm{dO}^{18} \text { ) }\end{array}$ \\
\hline
\end{tabular}


Table 1 (continued)

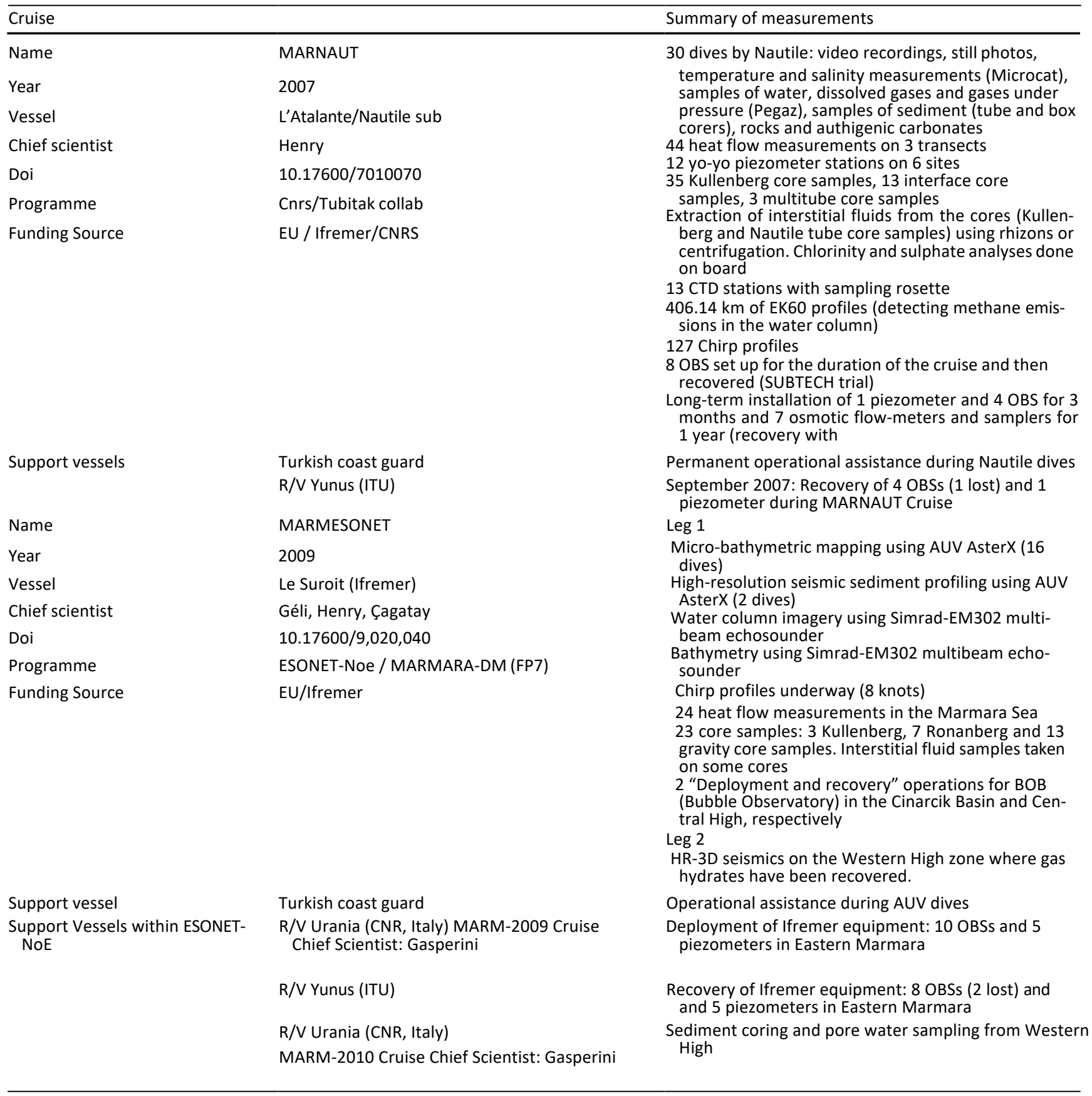


Table 1 (continued)

\begin{tabular}{|c|c|c|}
\hline \multicolumn{2}{|l|}{ Cruise } & \multirow{2}{*}{$\begin{array}{l}\text { Summary of measurements } \\
\text { Acquisition of high-resolution, 2D, seismic data using a }\end{array}$} \\
\hline Name & PIRMARMARA & \\
\hline & & \multirow{7}{*}{$\begin{array}{l}1500 \text { m long streamer ( } 240 \text { traces) } \\
31 \text { profiles (total length } 350 \mathrm{~km} \text { ) } \\
3 \text { deep areas : Central High, Central Basin and } \\
\text { Çınarcık Basin } \\
1 \text { shallow area on the Marmara southern shelf } \\
\text { (for investigation of the Messinian } \\
\text { unconformity) }\end{array}$} \\
\hline Year & (n) & \\
\hline Vessel & R/V Piri Reis (DEU, Izmir) & \\
\hline Chief scientist & Çıfçı & \\
\hline Doi & $?$ & \\
\hline Programme & ESONET-Noe / MARMARA-DM (FP7) & \\
\hline Funding Source & EU-FP7/DEU & \\
\hline Support vessel & Turkish coast guard & \multirow{2}{*}{$\begin{array}{l}\text { Operational assistance } \\
\text { Leg } 1 \text { (Géli) }\end{array}$} \\
\hline Name & MARSITECRUISE & \\
\hline Year & 2014 & \multirow{2}{*}{$\begin{array}{l}\text { Deployment of } \\
10 \text { stations ( } 4 \text { LDO, } 6 \text { from GEOMAR) for acoustic } \\
\text { geodesy }\end{array}$} \\
\hline Vessel & R/V Pourquoi pas + ROV Victor 6000 (Ifremer) & \\
\hline Chief scientist & Géli, Ruffine, Henry, Çagatay & 8 OBS (6 GEOMAR, 2 Ifremer). \\
\hline Doi & $10.17600 / 14000500$ & \multirow{3}{*}{$\begin{array}{l}\text { Leg } 2 \text { (Ruffine) } \\
5 \text { ROV dives for in situ observations and sampling } \\
35 \text { interface corers } \\
2 \text { blade corers }\end{array}$} \\
\hline Programme & MARSITE (FP7) & \\
\hline \multirow[t]{7}{*}{ Funding Source } & \multirow[t]{7}{*}{ EU/Ifremer } & \\
\hline & & 7 titanium bottle \\
\hline & & $\begin{array}{l}18 \text { gas samples taken with PEGAZ/ROV } \\
41 \text { direct in-situ measurements (with ROV) of gaz } \\
\text { flow }\end{array}$ \\
\hline & & $\begin{array}{l}\text { Sampling with ROV of } \\
28 \text { RAMAN measurements taken in situ (with ROV) } \\
\text { for gas compositions } \\
8 \text { CTD casts and water samplingusing rosette } \\
\text { fitted with methane sensors (Franatech and } \\
\text { MESSEA) Leg } 3 \text { (Henry, Çagatay) }\end{array}$ \\
\hline & & Calypso cores \\
\hline & & $\begin{array}{l}\text { Sediment penetrator }(3.5 \mathrm{kHz} \text { ) profiling } \\
\text { Recovery of } 1 \text { piezometer (deployed with Urania in } \\
\text { october } 2013 \text { ) }\end{array}$ \\
\hline & & Recovery of the 10 OBSs \\
\hline Support vessel & Turkish coast guard & Operational assistance during ROV dives \\
\hline \multicolumn{2}{|c|}{ Support Vessels within MARSITE Urania (CNR, Italy) } & \multirow{2}{*}{$\begin{array}{l}\text { Deployment of } 2 \text { piezometers on Western High on } \\
\text { September } 2013 \text { (recovered in nov } 2004 \text { with R/V } \\
\text { Pourquoi pas?) }\end{array}$} \\
\hline & MARM-2013 Cruise Chief Scientist: Gasperini & \\
\hline & R/V Yunus (ITU) & $\begin{array}{l}\text { Deployment of } 10 \text { OBS on Western in April } 2014 \\
\text { (recovered in nov } 2004 \text { with R/V Pourquoi pas?) }\end{array}$ \\
\hline & R/V Yunus (ITU) & $\begin{array}{l}\text { Recovery and deployments of Geomar and LDO geo- } \\
\text { detic stations in April } 2015\end{array}$ \\
\hline & R/V Yunus (ITU) & $\begin{array}{l}\text { Recovery and deployments of Geomar and LDO geo- } \\
\text { detic stations in April } 2015\end{array}$ \\
\hline
\end{tabular}

\section{Contribution to studies on the tectonic evolution of the NAF in the Marmara Region}

\subsection{Seafloor mapping and basins structure}

The bathymetric map after the Marmara cruise on R/V Le Suroit in 2000 (Rangin et al. 2001) revealed the main physiographic and structural features of the Marmara seafloor.
It replaced previous maps based on single-beam data (e.g. Aksu et al. 2000) and was used as a common reference for all subsequent studies in marine geosciences. In the absence of information on the deep crustal structure, this map gave rise to contrasting interpretations, emphasizing model ele- ments as diverse as the importance of extension (e.g. Parke et al. 2002, 2003); the presence of negative flower structure related to a deeply rooted, single master fault (e.g. Aksu et al. 2000; Yaltirak 2002); block or platelike junctions or 
geometry (Okay et al. 2000); pull-apart or transtensional jog activity at diverse scales (Armijo et al. 2002); evolution to strike-slip localization (Le Pichon et al. 2001).

Shortly afterwards, based on the modelling of the geodetically observed secular velocity field in northwestern Turkey, Meade et al. (2002) suggested that strain accumulation was highly localized in the Marmara region, confirming "the existence of a Marmara block delimited to the north by the northern branch of the North Anatolian fault (with the Marmara branch close to pure dextral strike slip over its whole length) and to the south by the southern branch" (quote from Le Pichon et al. 2003). Based on a complementary data set, including sparker and deep-towed highdefinition seismics (Demirbağ et al. 2003) and additional multichannel seismic lines from TPAO, Rangin et al. (2004) further proposed that most of the $\mathrm{N} 120^{\circ}$ trending normal faults framing the deep basins are now inactive, discarding the hypothesis that strain was distributed along presently active, extensional blocks. These findings eventually lead Sengör et al. (2005) to propose "a new look" of the North Anatolian Fault, including its westward continuation into the Sea of Marmara.

The interpretation of the deep reflection and wide-angle seismic data collected in 2001 during the SEISMARMARA cruise provided information that lead to embed all the different models into a broader and deeper context, discarding hypotheses involving crustal faults only with predominance given to extension, while supporting large, through-going strike-slip faults, cutting the whole crust down to the Moho, as quoted from Laigle et al. (2008): "Sections across the eastern half of the North Marmara Trough (NMT), crossing the Çınarcık and Imralı basins, revealed several faults hav- ing varying strike and varying proportions of normal and strike-slip displacement, that might be viewed as petals of a large scale negative flowerstructure that spreads over a width of $30 \mathrm{~km}$ at surface and is rooted deeper in the litho- sphere. Under the Central Basin a very thick sediment infill is revealed and its extensional bounding faults are active and imaged as much as $8 \mathrm{~km}$ apart down to $6 \mathrm{~km}$ depth. We interpret them as two deep-rooted faults encompassing a foundering basement block, rather than being merely pulled- apart from a jog in a strike-slip above a décollement".

Further analysis of the dense grid of multichannel seismic profiles along the southwestern margin of the North Marmara Trough reveals a dipping reflector through the upper crust with tilted basement blocks on top, while wide-angle reflection and refraction seismics using OBS reveal a significant and sharp reduction in Moho depth, in the order of $5 \mathrm{~km}$ beneath both the eastern and western rims of the North Marmara Trough, with a more progressive crustal thinning from the south (Bécel et al. 2009). More generally, the crys- talline basement exhibits sharp topography across the Cen- tral High, the Kumburgaz Basin and the eastern tip of the
Çınarcık-North Imralı Basin in an unexpected way with respect to the sea-bottom depressions (Bécel et al. 2010). Several large, tilted, basement blocks separate the deep basins as between the Çınarcık and Imralı basins, suggesting that the process of deformation partitioning may have taken place over one or even two faults across the North Marmara Trough, which may have changed activity in time and space (Bécel et al. 2010).

These findings were further detailed by the 3-D tomographic inversion of first arrival times of seismic shots recorded by the OBS and land-stations network (Bayrakci et al. 2013). Similar sedimentary thickness (> $6 \mathrm{~km}$ ) is observed below the North Imralı Basin (located on the southern continental shelf) than below its northern neighbours. The Tekirdağ and Central basins form a $60-\mathrm{km}$-long basement depression, as no basement high is found below the Western High (Note: this general picture was recently updated by Tarancıoğlu et al. (2020), using additional OBS data collected by TÜBITAK collected in 2006, and enriched by a discussion on the significance of the results for identifying locked and creeping sections along the Main Marmara Fault). Last but not least, gravity data collected during the MARSITECRUISE were merged with a global gravity model derived from satellite altimetry and were inverted, taking into account constraints from seismic refraction and receiver function studies, to quantify the amount of crustal extension and determine the geometry of the Moho over the whole Marmara area (Kendé et al. 2017).

\subsection{Re-evaluation of the seismo-tectonics of the Sea of Marmara within the Marsite Project}

The EU-funded Marsite Project (P. I. Nurcan Meral Özel, www.marsite.eu) provided the unique opportunity to reevaluate the seismo-tectonics of the Sea of Marmara, using all available marine data, including those collected during the Turkish-French collaboration programme: seismic lines, Görür and Elbek (2013) high-resolution bathymetry, chirp profiles, stratigraphic data from sediment cores, drill wells, etc.). The GIS fault map provided as Marsite deliverable D7.2 is based primarily on multichannel data and thus represents the fault geometry at a few kilometres depth within the syntectonic basins (Şengör et al. 2014). Faults are catego- rized as deep-rooted faults that also cut through the seafloor, blind faults, and shallow syn-sedimentary faults. For the purpose of hazard assessment, information from sediment sounder profiles and high-resolution bathymetry is essen- tial to assess fault activity and deformation style, but the geometry to be preferentially considered for the construction of earthquake scenarii is that of the faults at crustal level. Where crustal structure is poorly imaged below the Sea of Marmara Basin, the three-dimensional fault geometry at 
depths (Hergert et al. 2010, 2011) was largely inferred from seismic imaging in the syntectonic basins (Bécel et al. 2010; Carton et al. 2007). Fault models were further constrained, by taking relocated seismicity into consideration (Bulut et al. 2009; Karabulut et al. 2011; Schmittbuhl et al. 2015).

The work conducted within Marsite (e.g. Özel et al. 2017) resulted in the identification of which faults are cutting the seafloor (and thus currently active) and which ones do not (see deliverable D7.1 report in Henry et al. 2007). Several now inactive (or marginally active) fault systems appear to have played a role in the structuring of the basins. This is for example the case for the system of extensional detachments and tilted blocs between the southern shelf and the deep basins (Bécel et al. 2009) for the South Marmara Fault, connecting the Gemlik Bay to the Dardanelles (Le Pichon et al. 2003) and for an en-échelon system lying in prolongation of the Izmit fault (Grall et al. 2012). On the other hand, several arrays of normal faults observed at a shallow level in the sediment are not deeply rooted, and could result from the interaction of slope instability with underlying crustal deformation (Zitter et al. 2012).

\subsection{Currentknowledgeonthetectonichistory oftheNAFSysteminthe MarmaraRegion}

After 20 years of continuous marine investigations, the Marmara Sea floor has become one of the most well-known submarine domains on Earth. The currently active fault system only comprises a fraction of the faults that have been active since the initiation of the North Anatolian Fault, and this situation may account for the initial diversity of tectonic interpretations in the Sea of Marmara. Interpretations of deep seismic and bathymetric data have now largely converged to a scheme with a master fault - the Main Marmara Fault, or MMF, connecting the Izmit segment that ruptured in 1999 with the Ganos segment that ruptured in 1912-and subsidiary fault branches (e.g. Le Pichon et al. 2001; Armijo et al. 2002, 2005; Demirbağ et al. 2003; Rangin et al. 2004; Seeber et al. 2004, 2006; Meghraoui et al. 2012), a view further supported by studies of seismicity (e.g. Sato et al. 2014; Örgülü 2011). Remaining differences arise partly from the characteristics of the data sets used, and notably the resolu- tion and depth of investigation of seismic data.

The present-day knowledge on the tectonic evolution of the Marmara Region is summarized in the three following papers, that use all available data listed in § IV.2: Şengör et al. (2014) -see Fig. 1; Le Pichon et al. (2014); Le Pichon et al. (2016). Using mainly the data from the deep basins, Şengör et al. (2014) establish a sequence of faulting events in the northern Marmara shear zone from the Miocene to present, confirming that the shear zone has been evolving and becoming narrower since its inception. While a tendency is observed towards strain localization in a 7-to- $10 \mathrm{~km}$ swath along the Main Marmara Fault, some deformation is still accommodated over a broader area, and subsidiary faults display a complex history of fault activation/deactivation (Şengör et al. 2014). Using a comparable approach, based on a dataset enriched with seismic lines from the Marmara southern shelf, Le Pichon et al. (2014) completed the picture by mapping the evolution of the recently documented "South-Marmara Fault" (SMF) since the late Pliocene (Fig. 2).
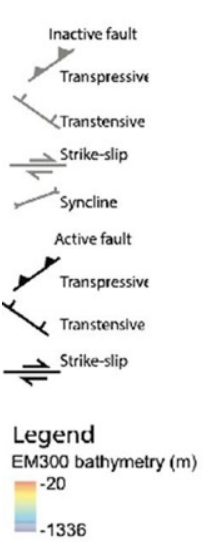

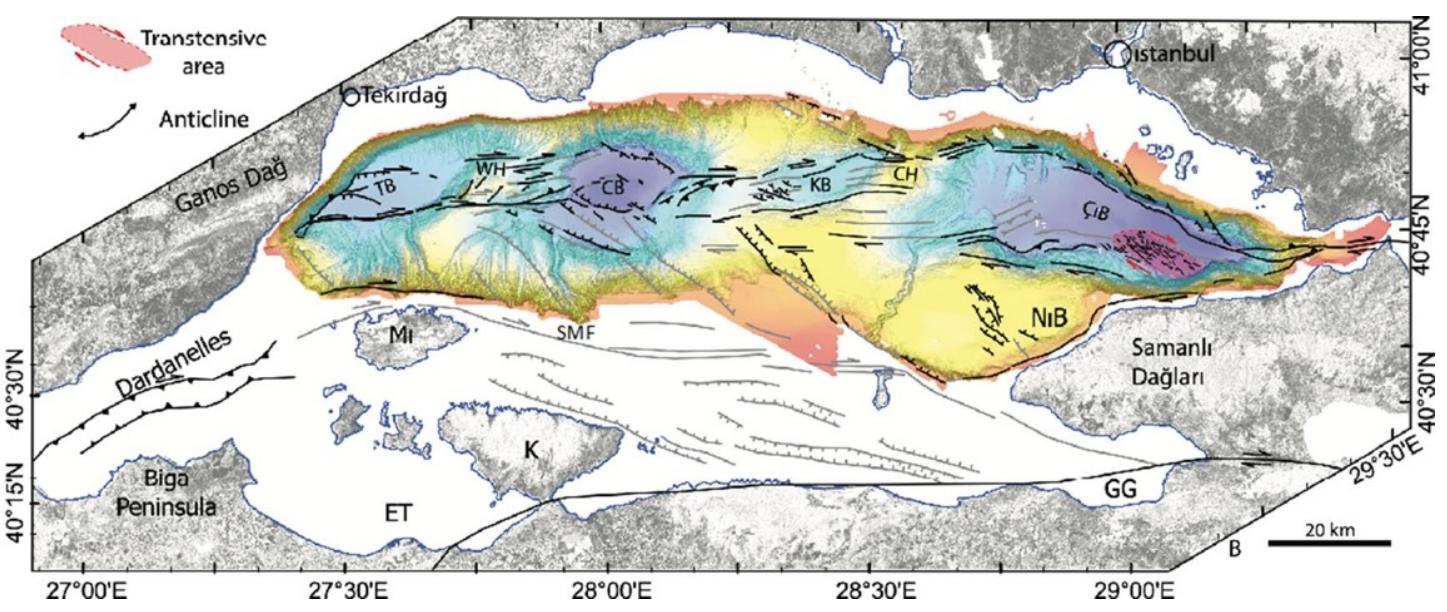

ve Arama Genel Müdürlüğü (General Directorat of Mineral Exploration and Research in Turkey) lines and TPAO lines, Türkiye petrolleri Anonim Ortaklığı (Turkish Petroleum Company). CB Central Basin, $C H$ Central High, çıB çınarcık Basin, ET Erdek Tombolo, GG Gulf of Gemlik, $K$ Kapıdağ Peninsula, KB Kumburgaz Basin, $M I$ Marmara Island, NıB North Imralı Basin, TB Tekirdag Basin, WH Western High, SMF South Marmara Fault (e.g. Le Pichon et al. 2014) 
Fig. 2 Cores from Marnaut (MNTKS) and MarmEsonet cruises (MEI) listed in the text (and used for paleoseismological studies in the Sea of Marmara (see coordinates in Table 2)

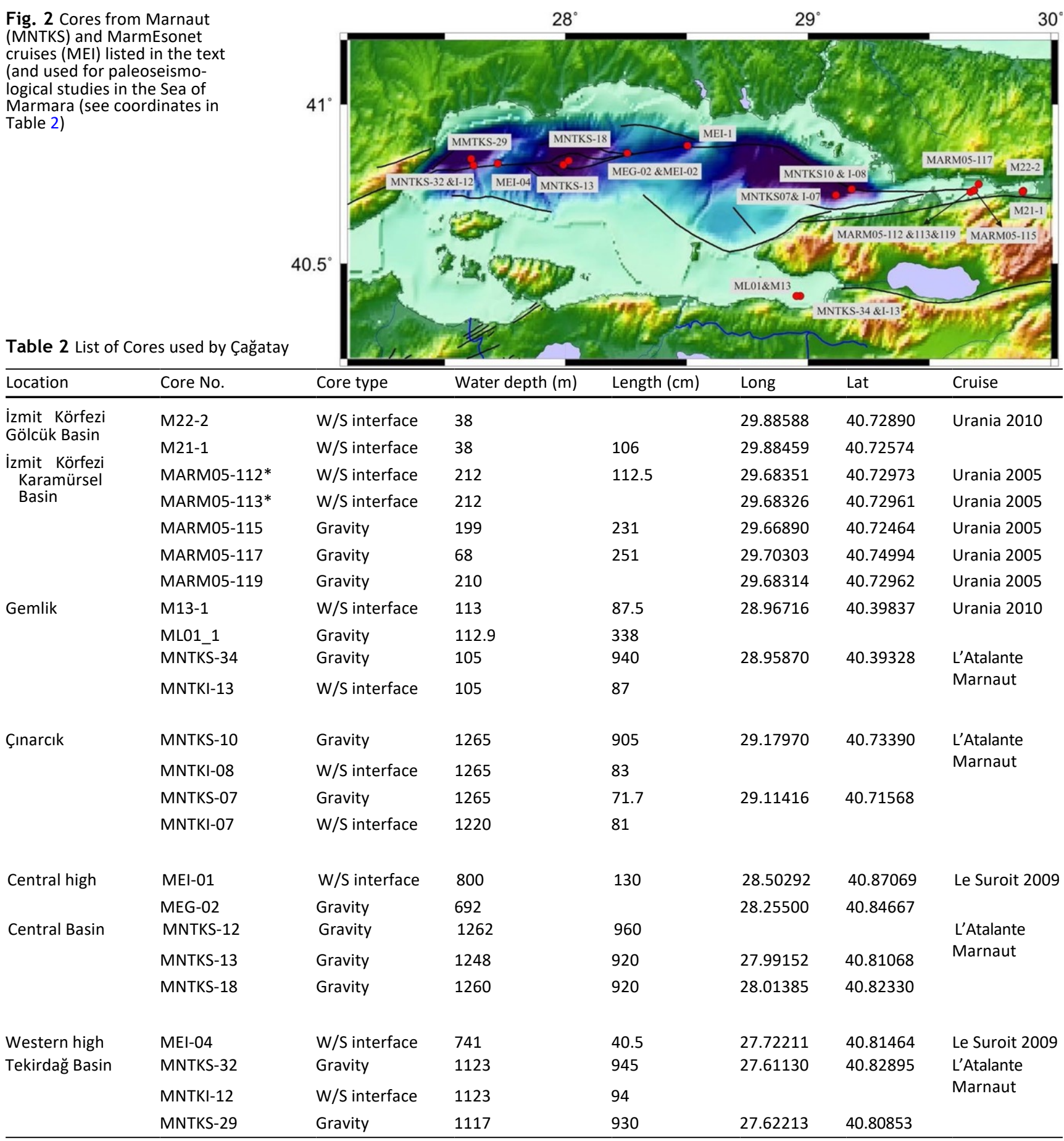

Table 2 List of Cores used by Çağatay

The initiation of the North Anatolian Fault in the Sea of Marmara was preceded by deformation affecting the Eocene-Oligocene Thrace basin, which peaked during the Late Miocene to Early Pliocene. "The beginning of the formation of a localized plate boundary occurred between 4.5 and 3.5 Ma at the location of the present Sea of Marmara by the initiation of a shear zone" (quote from Le Pichon et al. 2016). The first part of the formation of the Sea of Marmara was thus purely extensional. With crustal thinning possibly due to ductile lower crustal flow. At the present rate of areal extension derived from GPS data, about 5 Ma would be needed to explain the observed crustal thinning, which is probably slightly older than the onset of deformation related to the North Anatolian Fault. Hence, the areal extension rate was probably not constant, but may have peaked in the early Pliocene, as suggested by Le Pichon et al. (2016). The pre- sent strike-slip system that today cuts across the whole of Sea of Marmara began to develop after $2.5 \mathrm{Ma}$ and evolved 
since then, more likely through a progressive reorganization related to basin growth than as a sudden event (Grall et al. 2012; Sorlien et al. 2012; Akbayram et al. 2016). No major change in tectonic regime at the scale of the Sea of Marmara is required over the last $400 \mathrm{ka}$, although local variations in the rates of subsidence/uplift and in the strain distribution around the main fault are documented (Grall et al. 2012, 2013).

\section{Contributiontopaleo-oceanography and paleo-seismology}

\subsection{Paleoceanography}

The Sea of Marmara is currently connected to the Aegean Sea and Black Sea through the Dardanelles and Bosphorus straits having sill depths of 65 and $35 \mathrm{~m}$, respectively. Its hydrography is characterized by a two-way water exchange between the waters of the adjacent seas, with a permanent pycnocline located at $-25 \mathrm{~m}$ between the two water masses. Due to the shallowness of the sills, oceanographic and environmental conditions alternated between marine and lacus- trine phases during the Quaternary glacial and interglacial glacio-eustatic sea level changes. Despite its interesting oceanographic setting, palaeoceanographic studies on the Sea of Marmara were scarce before the international col- laborations, including the Turkish-French programme (e.g., Stanley and Blanpied 1980; Aksu et al. 1999).

Earlier studies hypothesized the late Quaternary palaeoceanographic history mainly on the basis of the global sea level curve rather than proper chronological dating. These studies were carried out on short gravity cores recovered mostly on board Turkish research vessels such as the MTA Sismik-1, Piri Reis and Bilim. A few of these studies, using radiocarbon datings, showed that Sea of Marmara was fresh- brackish lake during the late glacial period and that marine conditions were fully established $\sim 12$ ka BP. It was also dis-covered that the marine connection was followed by depo- sition of two sapropel units during the Holocene (Çağatay et al. 1999, 2000; Aksu et al. 2002).

The Turkish-French collaboration, using the French research vessels, recovered giant piston cores that sampled the older strata reaching back to the marine isotope stage (MIS-6). One $29 \mathrm{~m}$ long core (MD01-2430) recovered from the Western High extended back to $70 \mathrm{ka}$, and provided important paleoceanographic, paleoclimatic and tephra records (Vidal et al. 2010; Valsecchi et al. 2012; Çağatay et al. 2015a). The records revealed that the Sea of Marmara was fresh to brackish lake during MIS-4 to MIS2 and that a fully marine connection occurred at $12.6 \mathrm{ka}$ BP. Using the robust age model for the core, the Holocene main and the upper sapropel units were dated to $12.3-5.7 \mathrm{ka}$ and
5.4-2.7 ka BP, respectively (Çağatay et al. 2015a). Earlier, however, Vidal et al. (2010) documented that the initial marine connection took place at $14.7 \mathrm{ka} \mathrm{BP}$, and that the hydrologic change from lacustrine to marine conditions was gradual. These authors also documented an increase in the salinity and sea surface temperature in the Sea of Marmara after the Younger Dryas (12.7-11.5 ka BP).

Palynological analysis of core MD01-2430 by Valsecchi et al. (2012) documented the existence of climate changes during the Last Glacial Maximum (LGM)-Holocene. Cold and dry conditions prevailed during the LGM, the late glacial until the $B \varnothing l$ ling-Aller $\varnothing \mathrm{d}$ interstadial and during the Younger Dryas, whereas warm and moist climate conditions occurred during the early and middle Holocene. Multi-proxy analyses of the core by Çağatay et al. (2015a) showed a robust correlation with the north Greenland ice core (NGRIP) isotope (NGRIP members, 2004), Tenaghi Philippon pollen (Mül- ler et al. 2011) and Black Sea Ca (Nowaczyk et al. 2012) records during MIS-4 to MIS-1, indicating strong teleconnections between the NW Anatolia, Eastern Europeand the North Atlantic. Core MD01-2430 also revealed some interesting tephra layers that were matched with the $3.9 \mathrm{ka}$ Avellino eruption of Vesuvius-Somma, the $22 \mathrm{kyr}$ BP Cape Riva eruption of Santorini, and 39.3 ka Campanian Ignimbrite eruption of Campi Flegrei (Napoli) (Çağatay et al. 2015a). Study of piston cores recovered during the 2004 MARMARA-VT 67 cruise effectively elucidated the late Quaternary evolution of the northern shelf of the Sea of Marmara, and the water-exchanges via the Bosporus Straits during the Holocene (Eriş et al. 2007). Core MD-04-2745 on the northern shelf sampled two additional sapropel units depos- ited during the MIS-5. Data from this core, together with other staggered cores, allowed to date seismic stratigraphic units observed in Chirp profiles on the shelf, and determine the lake/sea level changes during the late Quaternary. Core MD04-2750 recovered a submerged channel-levee com- plex succession from the Marmara outlet of the Bosporus channel. Analyses by Eriş et al. (2007) concluded that the undulating unit in the succession was formed by a Black Sea outflow during the Younger Dryas, and that the radial delta lobe was sourced by a creek east of the Bosporus dur- ing Mid-Holocene rather than by the Black Sea outflow. However, these conclusions were later challenged by His- cott et al. (2008), Eriş et al. (2008). Utilizing pore-water isotope and salinity data from MARMARA-VT 67 cruise cores, Aloisi et al. (2015) carried out modelling studies that showed that the Marmara "Lake" waters prior to the latest marine reconnection were brackish ( $S \sim 4 \%$ ), and that following MIS-5, the freshening of the Marmara Sea by the Black Sea spill-out started at least $50 \mathrm{ka}$ BP.

Up to $20 \mathrm{~m}$-long piston cores were recovered from different parts the Sea of Marmara during MARSITECRUISE of $\mathrm{R} / \mathrm{V}$ Pourquoi pas? in 2014. Some cores were specifically 
located to date some seismic reflector surfaces and study paleoceanographic conditions during MIS-5 and 6(Çağatay et al. 2019; Kendé 2017 PhD thesis), and for palynological analysis (S. Leroy and D. Biltekin, pers. com.). Multi-proxy analyses of two Marsite cores from the Imralı Basin produced important results on stratigraphy and environmental and hydrographic changes during MIS-5 and 6 (Çağatay et al. 2019). The chronology of cores showed that the regional "Red" seismic reflecting surface of Sorlien et al. (2012) corresponded to a hiatus at the MIS 5/MIS 4 transition (70-80 ka BP) rather than 110 ka BP, estimated by these authors. The paleontological and geochemical results indicated that fresh-brackish lacustrine conditions existed in the Sea of Marmara during MIS 6 and that the transition to marine conditions during Termination II took place at $\sim 134$ BP. Marine conditions prevailed during MIS 5, except during MIS-5b stadial and three sapropels were deposited during MIS-5 interstadials a, c, and e. The geochemical proxy records of the MARSITE cores showed good correlation with the NGRIP oxygen isotope and regional terrestrial and marine records, and the strong influence of the North Atlantic climatic events. The core data also suggested that the Dardanelles sill depth was at $\sim-75 \pm 5 \mathrm{~m}$ during the reconnection at Termination II and at $-55 \pm 5 \mathrm{~m}$ during most of MIS 5, while the Bosporus sill depth was more stable at -35 to $-40 \mathrm{~m}$, similar to that of the current day depth (Çağatay et al. 2019).

\subsection{Paleo-seismology}

Sub-aqueous paleoseismological studies are important for obtaining recurrence interval of earthquakes over several thousand years. This information is in turn important for probabilistic earthquake risk assessment. Such studies in the Sea of Marmara started after the 1999 izmit earthquake (Polonia et al. 2002; 2004; McHugh et al. 2006), but increased considerably after Turkish-French geoscience collaboration, with the recovery of long piston cores and seafloor observations using ROV Victor and manned submersible Nautile (Armijo et al. 2005; Beck et al. 2007, 2015; Drab 2012; Çağatay et al. 2012; Eris et al. 2012; McHugh et al. 2014). Up to $38 \mathrm{~m}$-long cores allowed to obtain earthquake records extending back to several thousands of years, and to match the more recent ones with the 2500-yearlong historical records of the Marmara Region (Ambraseys and Finkel 1995; Ambraseys 2002; Guidoboni et al. 1994; Gui- doboni and Comastri 2005).

The sedimentological study of the 2001 MARMACORE cruise giant piston cores revealed that a considerable part of the sedimentary succession in the deep Marmara basins consists of turbidites, most of which were likely triggered by earthquakes. Radiocarbon dating of the cores indicated high sedimentation rates $(1-3 \mathrm{~m} / \mathrm{ka})$ in the deep Marmara basins, which could allow the individual seismic events to be distinguished in the sedimentary succession (e.g., Beck et al. 2007, 2015; Eriş et al. 2012). Moreover, Beck et al. (2007) also discovered a 5-8-m thick, 16-ka-old turbidite-homogenite (T-H) unit of tsunamogenic origin in cores MD01-2431 and MD01-2429 in the Central Basin. This distinct stratigraphic marker was clearly visible in the $3.5 \mathrm{kHz}$ seismic profiles, and used for sedimentation, slip and subsidence rates estimations. For example, Çağatay and Uçarkuş (2018) estimated average sedimentation rates over the last $16 \mathrm{ka}$ in the depocentre and basin margin of the Central Basin at $2.70 \mathrm{~mm} /$ year and $1.05 \mathrm{~mm} /$ year, respectively, and the sub- sidence rate in the depocentre at $6 \mathrm{~mm}$ /year.

The 4-5 m of piston cores and push cores, together with video recordings and micro-bathymetric mapping of fault scarps, obtained during the 2002 Marmarascarps cruise on board R/V L'Atalante with the ROV Victor providedimportant data on the paleoseismology (e.g. Armijo et al. 2005). Considering the fresh fault scarps in the Tekirdağ Basin and the Western High, Armijo et al. (2005) concluded that the $1912 \mathrm{Mw}=7.4$ Şarköy-Mürefte earthquake rupture extended all the way to the Central Basin. Uçarkuş (2010) used microbathymetry data and ${ }^{210} \mathrm{~Pb} /{ }^{137} \mathrm{Cs}$ dating of the disturbances in the push cores to show that the 1912 earthquake rupture extended at least to the Central High. Drab et al. (2012) analysed the long cores of the Marmarascarps cruise for turbidite paleoseismology and documented the records of the) 1894, 1509, 1343 and 740 earthquakes in the Çınarcık Basin; 1912 (Şarköy-Mürefte), 1766, 1343 (or 1354), 1063 and 557) earthquakes in the Tekirdağ Basin; and evidence of the 1912 Şarköy-Mürefte earthquake in the Western High and the Central Basin (all dates are Common Era).

The Marnaut Cruise in 2007 provided 9-10 m long piston cores, $\sim 1 \mathrm{~m}$ long water/sediment interface cores with undisturbed tops for paleoseismological studies as well as direct observations along the NAF. More than 20 MARNAUT piston and interface cores located in different basins and the highs were studied for turbidite paleoseismology using multi-proxy analyses and radionucleide datings by Çağatay et al. (2013) and three piston cores in the Central Basin by McHugh et al. (2014). More recently, the MARSITE- CRUISE with $R / V$ Pourquoi pas? recovered $\sim 20$-m-long cores from the Kumburgaz and İmralı basins. A 21-m-long Marsite core, dating back to 6.1 ka from the Kumburgaz Basin on the Central High segment, included 28 seismo- turbidite units, providing an average recurrence interval of 220 years (Yakupoğlu et al. 2019). However, the age-depth model indicated that the latest 1200-year-long record was missing, and thus, the archive for the recent major historical events such as of 1766 CE and 1509 CE could not be ascertained. Surprisingly, the MARSITE cores from the Imralı Basin contained almost no seismoturbidites, possibly 
suggesting that low magnitude earthquakes in the south did not produce any mass-wasting from the basin's southern margin.

The main conclusions of all the above seismoturbidite studies can be summarized as follows: (i) turbidites triggered by $\mathrm{Mw}>6.5$ earthquakes commonly consist of a coarse basal turbidite layer and an overlying homogeneous-looking mud layer (homogenite), forming together a turbiditehomogenite $(\mathrm{TH})$ unit. The TH units range from a few to tens of centi- metres in thickness, and usually have a sharp and erosional basal contact; (ii) the average recurrence interval over the last 5-6 ka is 200-300 years, compatible with GPS velocities and geological slip rates. However, the interval between two consecutive events can be highly variable; (iii) the records from different areas appear to be specific to the events on the nearby fault segment; (iv) basin depocentres and perched basins on highs are the best locations to obtain a complete earthquake record.

\section{Fluid emissions, faulting and seismicity}

\subsection{Fluid emissions and their origin}

Gas emissions in the water column in response to the August 17th, 1999 earthquake were observed by Alpar (1999) less than 1 month after the main shock, based on highresolution (Sparker) seismic data from the Gulf of Izmit and from the northern escarpment of the Cinarçik Basin. In the deeper basins of the Sea of Marmara, investigations in February 1999 with sediment sampling and a towed camera during the R/V Meteor, cruise 44 (e.g. Halbach et al. 2002; Kusçu et al. 2008) and in September 2002 with remotely operated vehicle during the MARMARASCARPS cruise on R/V Pourquoi pas? found indications of fluid expulsion along the active faults. These visual observations include: bubbles immediately beneath the seafloor at reduced sediment patches, notably on the Western High; active chimneys and carbonate crusts in the Central Basin and in the Tekirdag Basin-where fluid outflow is vis- ible, due to a contrast in optical indices (Armijo et al. 2005). After the first findings of Halbach et al. (2004), a shallow sulfate-methane reaction zone (SMRZ) was also detected in sediment cores sampled during the MARMARA-VT cruise from the same areas at depths of 3-5 $\mathrm{m}$ below the seafloor. Based on these observations, the high-resolution seismic data $(3.5 \mathrm{kHz})$ and deep-towed side-scan profiles collected by Le Pichon et al. (2001), were reprocessed, confirming the prob- able presence of trapped gases within the uppermost sedimentary sequences and gas escapes into the water column (S. Dupré, Pers. Comm.).

After numerous fluid vents and related features had been

discovered along the MMF, it became clear that the Sea of Marmara was an ideal site (possibly unique on Earth) to study the coupling between deformation, seismic activity, fluid flow and gas expulsion within an active, submarine transform fault. As a consequence, from 2007 onwards, a massive effort was undertaken with support of the EU, to test the hypotheses that "the fluid properties within the MMF evolve with time throughout an earthquake cycle", and that "some of these changes, or their consequences, can be recorded at the seafloor". In total. three major expeditions were organized with French vessels to study the submarine hydrogeological system and how it was coupled to the tectonic system, through the interaction of fluid pressure and stress state. These expeditions are described here after.

- MarNaut (2007): The MARNAUT expedition of R/V L'Atlante in 2007 (Henry et al. 2007), was mainly dedicated to: (i) in situ deep-sea sampling of fluids (including gas), carbonate crusts and bacterial mats along the NAF submerged system using the Nautile submersible (e.g. Bourry et al. 2009; Crémière et al. 2012; Burnard et al. 2012); (ii) gas emission mapping using single-beam 38 kHz echo-sounder (e.g. Géli et al. 2008); (iii) heat flow measurements (e.g. Grall et al. 2012); (iv) sediment coring; and (v) deployment of seafloor instrumentation (e.g. Tary et al. 2012; Tryon et al. 2012). Free gases were sampled at three sites, showing different composition and origin. Gases from the Western High-where gas hydrates were found-and from the Central High were predominantly methane gas of thermogenic origin and genetically related to the Thrace hydrocarbon Basin, whereas microbial methane gases were predominant in the easternmost Çınarcık Basin (Bourry et al. 2009; Ruffine et al. 2012). In contrast, dissolved gas extracted from water samples taken near the Tekirdag escarpment exhibit a predominance of methane, an abundance of $\mathrm{CO}_{2}$ and a mantle helium signature, suggesting a high permeability conduit from the mantle to the seafloor (Burnard et al. 2012). The diversity of pore fluids com- position reflect mixing of fluids from different sources (Tryon et al. 2010; Ruffine et al. 2015) varying with time, based on long-term monitoring of fluid properties (Tryon et al. 2012). Microbial chemosynthetic communities (Ritt et al. 2010) and carbonate crusts (Crémière et al. 2012) were found to develop near venting sites, in relation to the anaerobic oxidation of methane (AOM) and other heavier hydrocarbons. Lipid biomarkers in authigenic carbonates were investigated, providing evidence that AOM mediated by methanotrophic archaea (ANME) and their bacterial partners, is the major process leading to sequestration of methane-derived carbon (Chevalier et al. 2011, 2013).

- Marmesonet (2009) and PirMarmara (2010): The Marmesonet expeditions (Leg 1 and 2) of $R / V$ Le Suroit in 2009 were dedicated to: (i) the systematic mapping 
of the water column using the shipborne multibeam echosounder for gas bubble detection (e.g. Dupré et al. 2015; Grall et al. 2018a); (ii) high-resolution bathymetric mapping (using an Autonomous Underwater Vehicle -AUV-allowing a resolution of $2.5 \mathrm{~m}$ ) at three potential candidate sites for the deployment of multi-disciplinary observatories (Grall et al. 2013); (iii) the testing of seafloor instrumentation for the monitoring of fluid properties: piezometers, OBSs and acoustic bubble detector (e.g. Tary et al. 2012; Bayrakci et al. 2013; Tsang-HinSun et al. 2019); (iv) high resolution, 3D seismic imaging to characterize the plumbing system below the Western High, where gas hydrates were found, in association with a mud volcano (e.g. Thomas et al. 2012;). The 3D seismic imaging was complemented by high-resolution 2D profiling using a longer streamer during thePirMarmara Cruise of R/V Piri Reis (e.g. Saritas et al. 2018). These cruises helped identify the complex connections between the fault network and the manifestations of fluid activ- ity at the seabed (gas emissions, cold seeps, pockmarks, mud volcanoes, sediment unstabilities, etc.). It seems one outcome of the Marmesonet cruise is an estimation of the MMF geological slip rate from offset geomorphological features and mass transport deposits (Grall et al. 2013).

- MarsiteCruise (2014): The MarsiteCruise expedition was divided into three legs. The first was devoted to the deployment of submarine instrumentation to collect long period series of geodetic and geophysical data (in col- laboration with GEOMAR) to determine correlations between fault motion, intermittent fluid discharge and micro-seismicity (Sakic et al. 2016; Lange et al. 2019). The second leg was dedicated to ROV-Victor 6000 dives to investigate the geochemical dynamics of selected cold- seep sites (Fig. 4). During the third leg, sediment samples from long-gravity cores were collected to complete dat- ing of seismic reflector surfaces in view of establishing chronostratigraphy for the last hundred thousand years. A Special Issue, entitled "Fluids and processes at the seismically active fault zone in the Sea of Marmara", was published in 2018 in Deep Sea Research, Part II, provid- ing the state of knowledge on the links between fluids, faults, seismicity and the hydrocarbon system in the Sea of Marmara (Ruffine et al. 2018a). A new strategy was deployed during the MarsiteCruise for gas-seep sampling and for developing new proxies to relate fluid properties to fluid migration history. As a result, the gas bubbles emitted at the seafloor were shown to be mixtures of pri- mary and secondary microbial gases with thermogenic and mantle-derived gases with an asymmetric contribu- tion of each source (Ruffine et al. 2018b). In addition, the authigenic carbonate crusts sampled at the seafloor during the cruise were dated less than $9.6 \mathrm{kyr}$ BP and a majority were younger than 1000 years, suggesting that authigenic carbonates could yield archives of fluid emission activity correlatable to historic seismicactivity (Çağatay et al. 2018; Teichert et al. 2018). The geological and biological diversity of fauna was also investigated, showing that seeps sustain typical Mediterranean cold seep fauna, but also unusual communities likely related to the interaction of seeps with hypoxic conditions (Ondréas et al. 2020). These results naturally triggered renewed interest for assessing the hydrocarbon potential of the Marmara Sea basin (Palabıyık et al. 2020).

\subsection{Relationswith faultingand seismicity: summary of current knowledge}

The new knowledge considerably improves our understanding of the fluid system in relation to faulting and seismicity in the Sea of Marmara and more generally in submarine environments. The EM-302 multibeam survey carried on R/V Le Suroit during the MARMESONET cruise (2009) provided a nearly continuous and uniform coverage of acoustic anomalies in the water column indicative of gas emissions at the seafloor. The superposition of the acoustic anomaly map on the active fault map (Fig. 3) indicates that (quote from Dupré et al. 2015): "gas emissions are spatially controlled by a combination of factors, including fault and fracture networks in connection to the MMF system and inherited faults, the nature and thickness of sediments (e.g. occurrence of imper- meable or gas-bearing sediments and landslides), and the connectivity between the seafloor Dresen and Malin (2017) and gas sources, particularly in relation to the Eocene Thrace Basin. The relationship between seepage and fault activity is not linear, as active faults do not necessarily conduct gas, and scarps corresponding to deactivated fault strands may continue to channel fluids. Within sedimentary basins, gas is not expelled at the seafloor unless faulting, deformation, or erosional processes affect the sediments. On topographic highs, gas flares occur along the main fault scarps but are also associated with sediment deformation."

Henry et al. (2018) later applied a statistical approach to characterize quantitatively the relationship between seeps and active fault and found that gas emissions are more abundant within a swath of 900-1000 m (half- width) from an active fault, which corresponds to the width of the deformation zone observed at the seafloor in association with major faults. To explain the remain- ing $20 \%$, Grall et al. (2018b) distinguish gas migration pathways controlled by sedimentary structure from those controlled by faults. A conceptual model is further pro- posed, in which (quote from Henry et al. 2018) (see also Okay and Aydemir 2016): "Updip migration along perme- able strata will result in gas migration toward the edges of the basins and its accumulation in anticlines and at sedi- mentary discontinuities (sediment-basement contact and 

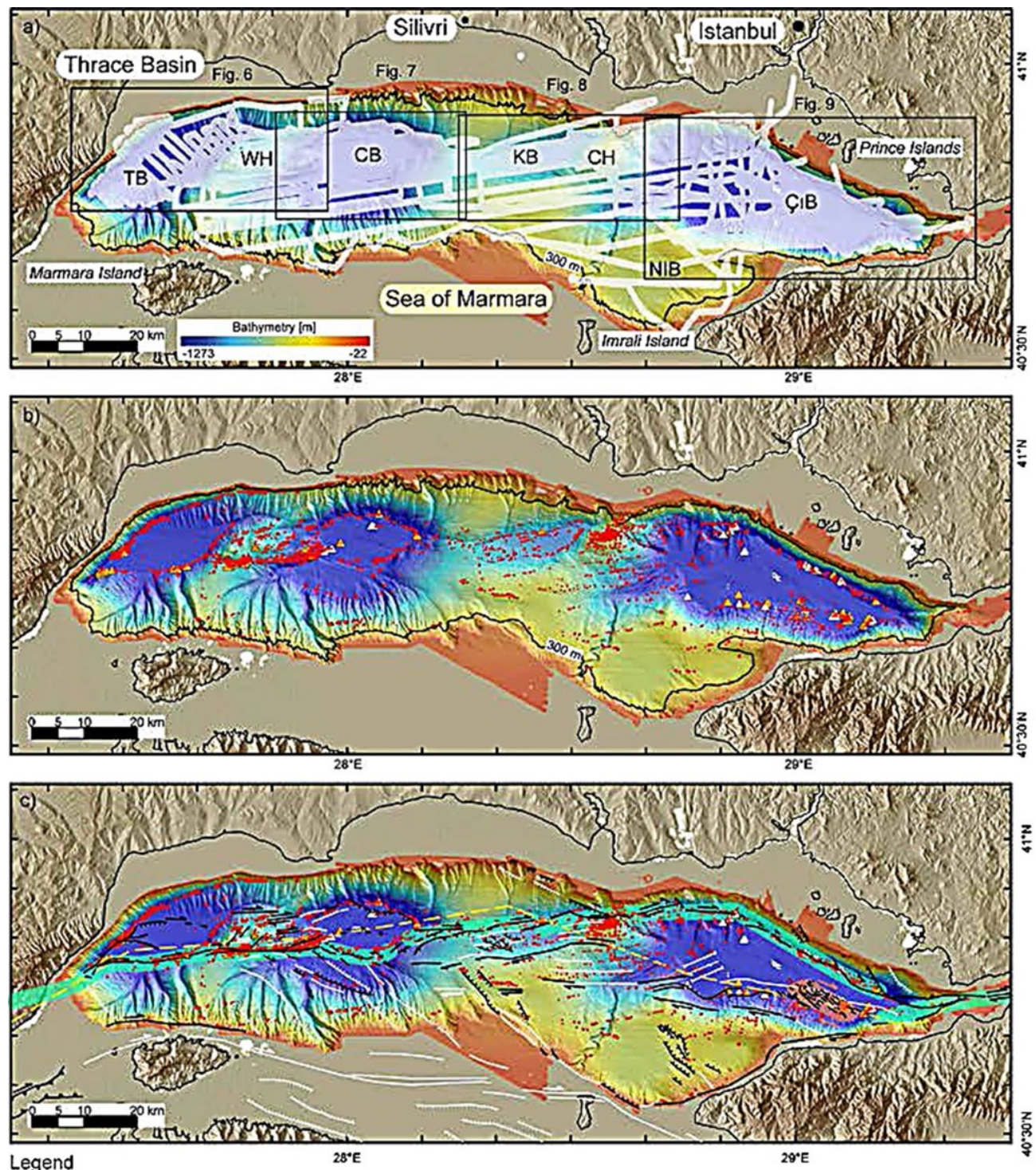

Structural features from Sengör et al., [2014]

Thactive ranti Active fault

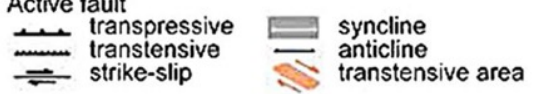

Main Marmara Fault
Le Pichon et al., [2001]

_ _- Offshore extent of the Eocene Thrace

Basin, Le Pichon et al., [2014]

Acoustic gas emissions in the water column

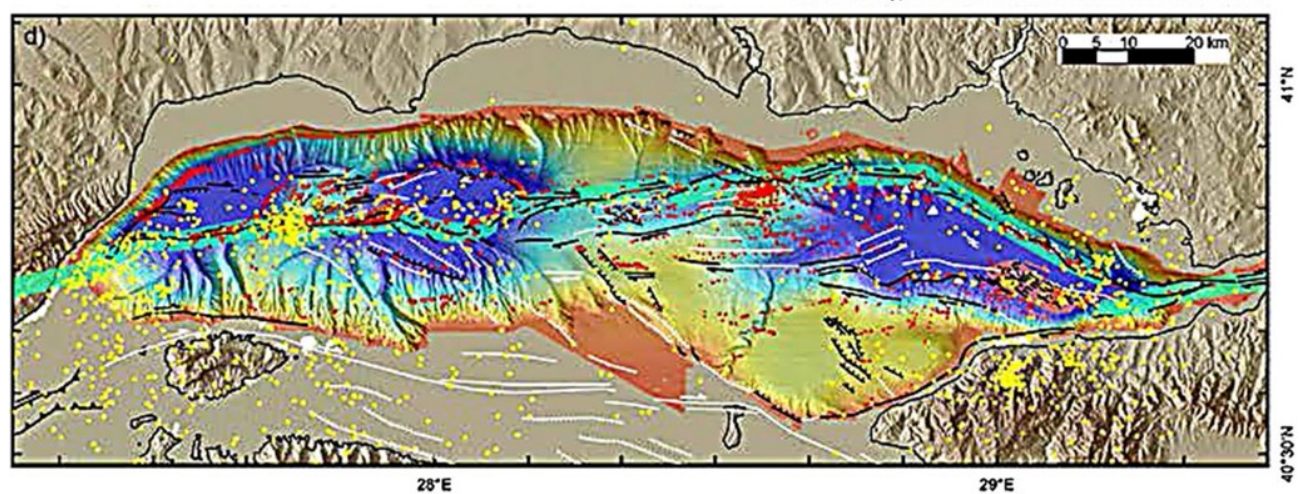


4 Fig. 3 After Dupré et al. (2015). Relations between active gas emissions and active faulting. a EM302 water column multibeam track lines during the 2009 Marmesonet expedition. The white buffer along the navigation stands for the insonified zone within which gas bub- bles are detectable. $T B$ Tekirdağ Basin, $W H$ Western High, $C B$ Cen- tral Basin, $C H$ Central, $K B$ Kumburgaz Basin, ÇıB Çınarcık Basin, NIB North Imrali Basin. $\mathbf{b}$ The 2-D Marmara shaded bathymetry map with gas flare distribution, c fault networks from Sengör et al. [2014] with the offshore extent of the Eocene Thrace Basin from Le Pichon et al. (2014), and d microearthquake epicenters (yellow dots) recorded between 2005 and 2011 [Sengör et al. 2014; H. Karabulut, personal communication, 2013]. White, orange, and redmarks stand for water column acoustic anomalies recorded in 2000, 2007, and 2009, respectively. The maps illustrate the 2009 seepage activity over more than 1 month (from 4 November 2009 to 14 December 2009). Each of these acoustic anomalies is displayed as a $150 \mathrm{~m}$ radius red dot

intra-sediment onlaps). Gas is eventually expelled along anticlines through extensional structures or along basin edges. This pattern will be observed if faults do not have high permeability, which may be the case during the interseismic period if faults are locked. It can be suggested that this is the current state in the Central High zone. After an earthquake, permeability increase in the ruptured fault enables focused fluid migration through the fault zone and a transient redistribution of gas emission sites at the seafloor. If fault creep also enhances permeability, permanent fluid expulsion through creeping fault zones could occur, following a similar pattern as for post-seismic fluid flow. It can be suggested that this is the case for the Western High zone". Eventually, Henry et al. (2018) put this difference in perspective with recent work showing that "creep is occurring on the western segment of the Main Marmara Fault (this also causing micro-seismicity) while the central Istanbul-Silivri segment may have remained locked since the 1766 magnitude 7 + earthquake. This suggests that aseismic slip (and not only earthquake occurrence) effectively maintains high permeability conduits in fault zones in sediments."

Let us now address the question of the relations between gas emissions and micro-seismicity. Géli et al. (2018) note that the occurrence of gas emissions appears to be cor- related with the distribution of micro-seismicity, particu- larly on those segments where creeping is suspected along the MMF. Indeed, events of magnitude greater than $\sim 4.2$ regularly occur in the Western Sea of Marmara, generat- ing large sequences of aftershocks below sites where the density of gas emissions is at a maximum along the MMF. A large number of the aftershocks that followed the M 5.1 earthquake of 25th July 2011 occurred below the Western High, within a zone where pressurized gas is expected to migrate along the MMF, all the way up through the surface sediment layers. Hence, they concluded that gas-related processes should also be considered for a complete inter- pretation of the micro-seismicity $(\sim M<3)$, particularly at supposedly creeping segments, where high permeabilities within the damage zone are expected to channel gas up to the seafloor.

\subsection{Implicationsforearthquakehazardassessment}

The geometry of the MMF is now well established. One of the many questions facing the scientific community is how the MMF will rupture? In one single segment? Or in multiple segments? What is more, active faults caus- ing offsets within the recent sediments have been identified, as well as buried faults which may be interpreted as blind faults with uncertain activity (Şengör et al. 2014), suggesting that ruptures may happen outside the MMF fault plane. While predicting earthquakes on out-of-plane faults (secondary or splay) is generally considered to be impossible, active research is presently ongoing to determine the seismological behavior of the different segments along the MMF, which involves $75 \%$ of the geodetic strain across the Sea of Marmara (e.g. Meade et al. 2002; Hergert and Heidbach, 2010; Reilinger et al. 2010; Le Pichon et al. 2016; Özbey et al. 2021; Zabci et al. 2019). Numerous recent papers have been dedicated to address-ing which segments are creeping and which are locked along the MMF.

Land-GPS data show a lack of elastic strain accumulation along the central and western part of the MMF (Ergintav et al. 2014). Inversion of data in 3D finds heterogeneous locking on the MMF (Bulut et al. 2019; Klein et al. 2017), but today, land-GPS data alone cannot yet resolve the distribution of interseismic loading rates vs. aseismic slip rates on the central and western part of the offshore fault (Klein et al. 2017). Seismology approaches suggest that the MMF has a deep creep component in the western Sea of Marmara, but not on the Central High nor on the Prince Islands seg- ment (Bohnhoff et al. 2013, 2016, 2017; Schmittbuhl et al. 2015; Uchida et al. 2019). The Western High and the Central Basin segments are characterized by a higher level of back- ground seismicity that at the adjacent segments (Schmittbuhl et al. 2016) and by the common occurrence of repeating small earthquakes (Bohnhoff et al. 2017; Schmittbuhl et al. 2016). Furthermore, acoustic ranging experiments indicate an aseismic creep rate at the seafloor of 9-16 mm/year on the Western High (Yamamoto et al. 2019) and no creep at the Central High and Kumburgaz Basin, where the level of microseismicity is notably low (Sakic et al. 2016; Lange et al. 2019). Joint inversion of land GPS and marine geodesy constraints shows that there is no incompatibility between these two data sets and that the MMF has significant creep west of $28.2^{\circ} \mathrm{E}$ but is essentially locked eastwards (Özbey et al. 2021). These conclusions are also supported by other approaches, including the analysis of seismic velocity data (e.g. Tarancioğlu et al. 2020). 

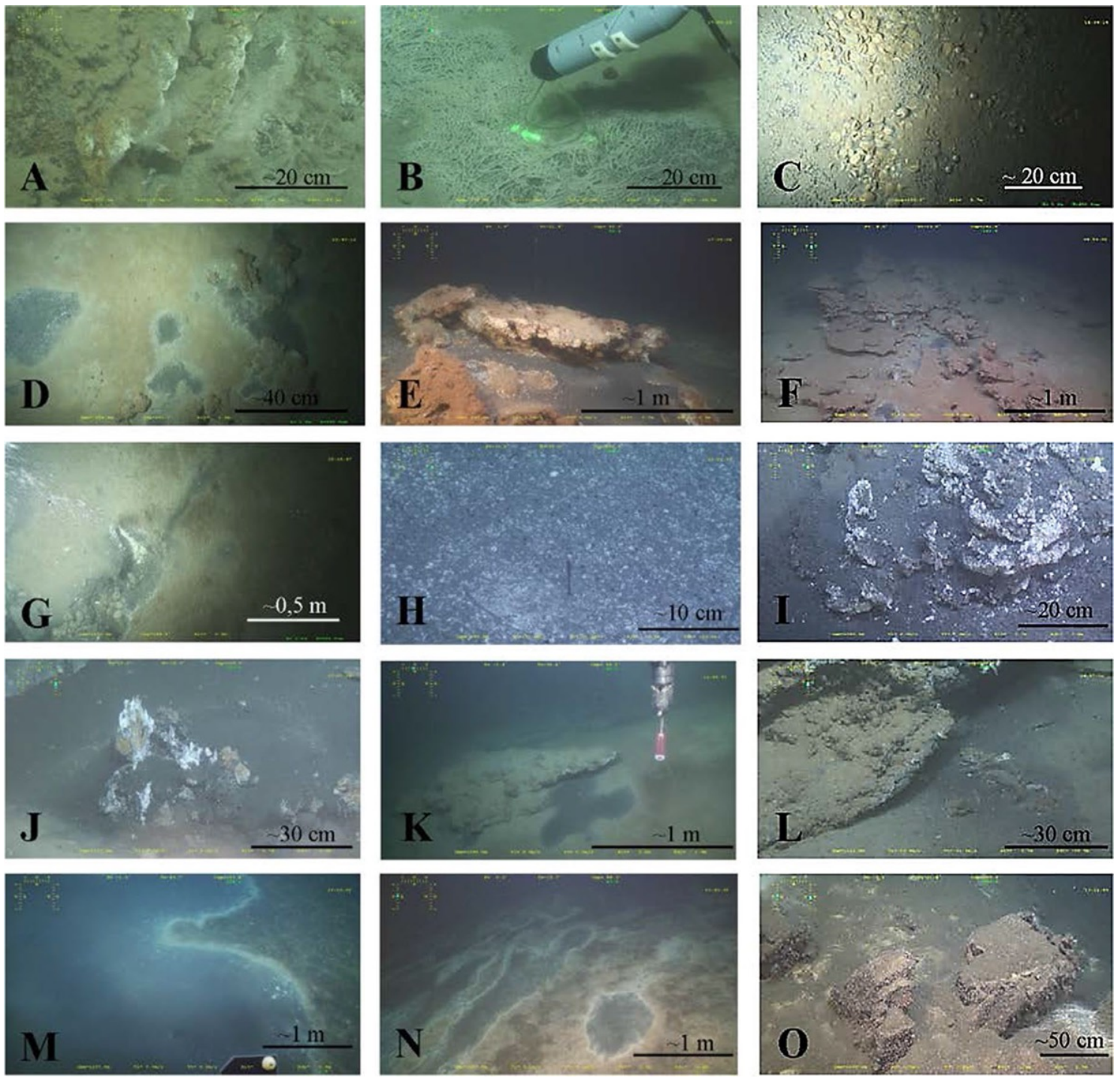

Fig. 4 After Ruffine et al. 2018b. Seafloor observations with ROV Victor reported during the MARSITE (MRS) Cruise on $R / V$ Pour- quoi pas? See also http://dx.doi.org/10.1016/j.dsr2.2018.03.006. a-c Dive MRS-DV592 starting from eastern border of the Kumbur- gaz Basin to the Central High. Black patches associated with bacte- rial mats and fauna (a); In-situ RAMAN spectrometer analyzing gas streams bubbling from sites covered with specific white spaghetti-like bacterial (b); Hemipelagic sediment covered at some seep sites by dense accumulation of bivalve shells, presumably dead (c). $\mathbf{d}-\mathbf{f}$ Dive MRS-DV593 on the Western High. Areas with reduced black sediment associated with both bacterial mats (narrow or large ones) and carbonate crusts (d); Large areas of massive carbonate crusts, with or without bacterial mats around and discontinuous oil seeps (e); Brown soft sediment present with bioturbation as well as dead or alive sea urchins outside the seepage areas covering carbonate crusts. g-i Dive MRS-DV594 in the Tekirdag Basin. Intensive bubbling site at the foot of the Tekirdag escarpment discovered during MarNautCruise and called "Boris Bubbler" after Henry (2007) (g); Wide spread oil

If we superpose these results-on the distribution of creeping segments-and those on the distribution of the zones where the amount of gas emissions is at a maximum seep emitting oil droplets, creating a cloud of beads rising into the water column (h); seep discharging a shimmering fluid through small carbonate chimneys along with continuously or intermittently gas and oil seeps (i). j-I Dive MRS-DV595, a 2-km length track from east to west along the SE border of Tekirdag Basin. Site named "Jack the Smoker", a chimney covered with microbial mats and discovered during Marnaut cruise (Burnard et al. 2012; Tryon et al. 2010), revisited during MARSITE cruise (j); near-by, active bubbling site, located at a canyon outlet south of Tekirdag basin (k); bubbling site character-ized by corals, anemones and mussels fixed on carbonate crusts (I). $\mathbf{m}-\mathbf{0}$ Dive MRS-DV596 in the Cinarcik Basin. Large black reduced sediment patches with surface areas of $\sim 100-200 \mathrm{~m} 2$, bacterial mats (orange and white) and carbonate crusts ( $\mathbf{m})$; Seeps associated with numerous massive carbonate crusts of few meters scale in dimension and elongated black ( $\mathbf{n})$; Diversified fauna observed upon and around carbonate crusts, along the SE border at the foot of the slope: amphipods, anemones, corals and crustaceans (o)

(Dupré et al. 2018), we note a systematic correlation between the two (Henry et al. 2018). In summary, for the Western High, we have the following sequence: (i) relation 
seismicity/creep: (Schmittbuhl et al. 2015, 2016); relation seismicity/fluids: (Géli et al. 2018); relation creep/fluids: (Henry et al. 2018); confirmation of creep using acoustic geodesy: (Yamamoto et al. 2019).

All these findings draw up new research avenues regarding the possible use of gas emissions mapping as a proxy for characterizing the behaviour (locked vs creeping) of the MMF, and more generally, the behavior of submarine transform-fault segments (e.g. Hensen et al. 2019).

\section{Implementing seafloorobservatories in the Sea of Marmara}

\subsection{Present situation}

The turn of the century was also a time when major deep seafloor, multidisciplinary observatory programmes were being initiated world-wide, giving birth to today's large infrastructures such as: "Ocean Network Canada" in Canada (https:// www.oceannetworks.ca/); Ocean Observatory Initiative in the USA (https://oceanobservatories.org/); DONET (https:// www.jamstec.go.jp/donet/e/) and S-Net (https://www.bosai. go.jp/e/) in Japan. In Europe, the EU was promoting the European Seafloor Observatory Network (ESONET) and European Multidisciplinary Sea Observatory (EMSO), aspiring to developing multidisciplinary seafloor observa- tories off the coast of European and associate countries, e.g. including Turkey (Çağatay et al. 2015b) In this context, the Sea of Marmara Sea was considered as the ideal location for implementing seafloor observatories geared towardshazard assessment, due to (i) the potentially high societal impact, in a region where more than 15 millions people are under the threat of seismogenic hazard in the whole MARNAUT Area;

(ii) the logistics, favored by the proximity to the coastlines (only 5-30 km), which make for cost-effective and realistic the establishment of permanent seafloor observatories; iii) the deformation rates $(20 \mathrm{~mm} /$ year $)$ are very high compared to all other marine sites in Europe, resulting in active sub- marine processes that are measurable on short time scales. The route towards permanent, real-time, multi-disciplinary seafloor observatories is very long (Fig. 4). However, some progress has been made over the last decade:

- Based on the results of the MarNaut cruise, the EU successively funded the Marmara Demonstration Mission (DM) as part of ESONET-NoE (cf Ruhl et al. 2011 and http://www.esonet.marmara-dm.itu.edu.tr/) and the Marsite Project (P.I. Nurcan Özel; cf Özel et al. 2017 and http://marsite.eu/), in which one work package was dedicated to marine operations (including MARSITECRUISE of $R / V$ Pourquoi pas?), for preparing the implementation of multidisciplinary seafloor observatories.
Four optimum sites for future deployments of multiparameter, permanent observatories were identified at, respectively: the Western High, the central basin, the Central High and at the entrance of the Gulf of Izmit. Moreover, the deployment of autonomous, innovative instrumentation provided the expertise and know-how for monitoring pore fluid properties on the seafloor Çağatay et al. (2015a). The instrumentation included: acoustic bubble detectors (e.g. Bayrakci et al. 2014); aqueous flux meters for very low to moderate discharge rates (Tryon et al. 2012); piezometers (Henry et al. (2007); oceano- graphic sensors (temperature, salinity, current velocity, dissolved oxygen, turbidity) and methane sensors (e.g. Embriaco et al. 2013); and also, extensometers for acous- tic ranging for seafloor geodesy (Sakic et al. 2016; Lange et al. 2019).

- At the same time, the Marmara Sea Bottom Observatory (MSBO) project of the Kandilli Observatory and Earthquake Research Institute (KOERI) was funded by Turkish Telecom, independently of ESONET. Five cables connecting land stations to seafloor observatories (including broad band seismometer, accelerometer, differential pressure meter, hydrophone, temperature meter, current meter, and tiltmeter sensor) were operated from 2009 to 2012 by KOERI as part of the Turkish national network for earthquake and tsunami hazards monitor- ing (e.g. Kalafat et al. 2009; Kalafat et al. 2009; Gürbüz et al. 2011; Kalafat et al. 2012; Gürbüz et al. 2009). Other international bilateral collaborations were established by KOERI in the field of marine geosciences, particularly with JAMSTEC (Japan Agency for Marine-Earth Science and Technology) for OBS deployment (e.g. Yamomoto et al. 2019) and acoustic extensometers for seafloor geod- esy (e.g. Yamamoto et al. 2019).

\subsection{Challenges in seafloor geodesy}

The relative motion between Anatolia and Europe is constrained by data from space geodesy (e.g. Reilinger et al. 2006,2010 ) and amounts to $24 \pm 1 \mathrm{~mm}$ /year of the geodetic slip rate on the North Anatolian Fault. The North Anatolian fault system divides westward into a northern fault branch crossing the Sea of Marmara between Izmit Gulf and Ganos and a Southern fault system, which itself comprises the Gemlik fault and its offshore prolongation (the Middle Branch) as well as the Southern Branch. The strain partitioningbetween the two systems is such that the northern fault branch takes up most of the strike-slip component of plate motion while the southern fault system accommodates oblique extension (e.g. Flerit et al. 2003; Reilinger et al. 2010; Le Pichon et al. 2016). Therefore, a critical issue for seismic hazard assessment is to determine the mechanical behaviour of the different segments along the MMF, and thereby identify those with the highest 
probability to rupture during the next expected Marmara earthquake. For instance, the low, or absence of, interseismic loading in the Istanbul area at about $10 \mathrm{~km}$ distance from the fault is puzzling (Ergintav et al. 2014; Le Pichon et al. 2003). But the presence of the water cover above the fault trace and the absence of islands to the south of the fault limits the use of land-based GPS data in estimating the strain accumulation and slip deficit along each of the segments. The efforts made so far to collect acoustic-based geodetic data are encouraging (e.g. Sakic et al. 2016; Lange et al. 2019; Yamamoto et al. 2019). However, acoustic ranging techniques are restricted to very small areas of a few kilometres in length along the fault, which limits their interest for studies at the scale of the entire submarine fault. Moreover, the integration of acoustic ranging data in GPS-based networks with the required accuracy is a challenge that appears to be unreachable today. Technical solu- tions, hereafter called GNSS/A do exist, combining acoustic transmission in the water column and the Global Navigation Satellite System (e.g. Chadwell 2017). In the next section, we propose to include GNSS/A geodesy in the Maregami concept described hereafter.

\subsection{The Maregami concept including GNSS/A}

Distributed Acoustic sensors -DAS- based on fiber optics, is certainly the most promising technology for future seismological monitoring in the Sea of Marmara (e.g. Sladen et al. 2020). Still, we present here the Maregami concept, which pre-dates the DAS revolution (Lindsey et al. 2017), as it allows multi-parameter seafloor monitoring and possible integration in GNSS.

In 2017, ANR and TUBITAK (respectively, the French and Turkish national funding agencies for research) decided to fund the 3-year-long MAREGAMI Project (P.I.s Louis Géli -Ifremer- and Ziyiadin Çakir-ITU). One of the objectives of the project was to design an optimized submarine monitoring observatory system, with the following attributes: (i) simple; (ii) robust; (iii) fully integratable in the local monitoring network; (iv) densely distributed (spatially) on the Marmara seafloor. To ensure the adequate spatial distribution, the"MAREGAMI observatory concept" was proposed as a versatile and multidisciplinary alternative to cabled sea-floorobservatories. It is based on three components (Fig. 5): (i) a sea-surface "buoy» or "platform» for energy production from solar panels and data transmission to land; (ii) three mooring lines and a link from surface to sea-floor, consisting of an electro-mechanical umbilical for energy transfer and data communication; (iii) a central node equipped with meas- uring instrumentation and connected (via electric cables) to four remote nodes, located $5 \mathrm{~km}$ away. Based on the results of the ESONET-NOE and MARSITE projects, three sites were selected: the Western High, the Central

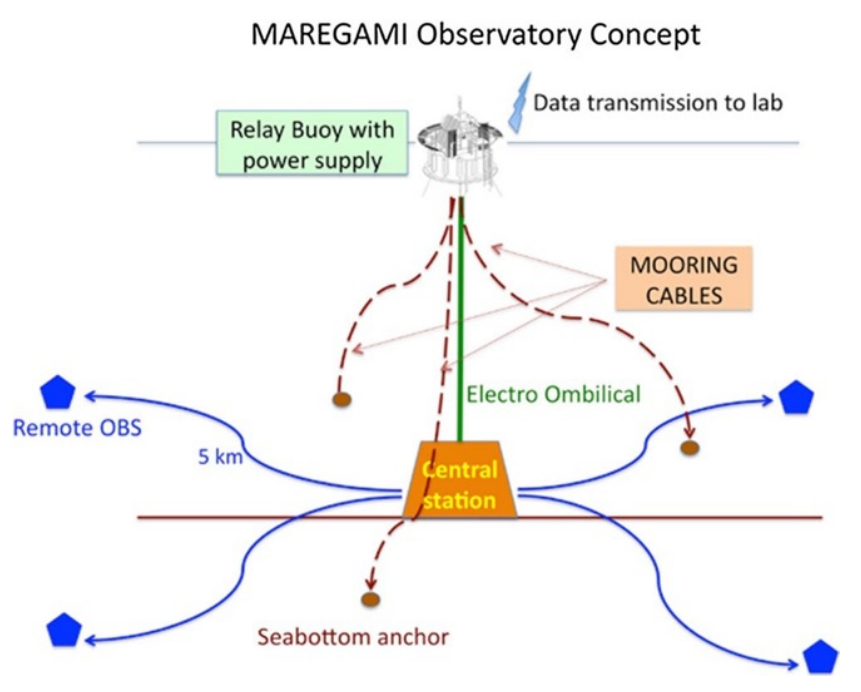

Fig. 5 In 2017, ANR and TUBITAK decided to fund the 3 years- long MAREGAMI Project, with the objective to design an opti- mized submarine monitoring observatory system, having the fol- lowing attributes: i) simple; ii) robust; iii) fully integratable in the local monitoring network; iv) densily distributed (spatially) on the Marmara seafloor. To ensure the adequate spatial distribution, the"MAREGAMI observatory concept" was proposed as a versatile and multi-disciplinary alternative to cabled sea-floor observatories. It is based on three components (see lower panel): (i) a sea-surface "buoy" or "platform" for energy production from solar panels and data transmission to land; (ii) three mooring lines and a link from surface to sea-floor, consisting of an electro-mechanical umbilical for energy transfer and data communication; (iii) a central node equipped with multi-parameter instrumentation and connected (via electric cables) to four remote nodes, located $5 \mathrm{~km}$ away. Work is presently in progress for integrating the possibility of collecting GNNS/A data in the MAREGAMI concept

Basin and the Central High (for details, see technical reports: Abalain 2018; Bompais 2018; Lagadec 2018). Work is currently in progress for the possible integration of GNNS/A data acquisition in the MAREGAMI concept.

\section{Conclusions andperspectives}

Based partly on the several seismic and bathymetric surveys carried out within the framework of Turkish-French collaboration, there is no question today that the western prolongation of the NAF within the Sea of Marmaracomprises a through-going dextral strike-slip fault-called the Main Marmara Fault - that enters the sea through the gulf of Izmit and joins the Ganos Fault at its western extremity. Also, the MMF holds about $75 \%$ of the geodetic slip rate (Le Pichon et al. 2016; Zabci et al. 2019), which suggests that at least $25 \%$ of the displacement is taken outside the MMF principal shear zone, on other fault branches (e.g. 3-4 mm/yr on the southern NAF branch in Gemlik Bay (Polonia et al. 2004; Gasperini et al. 2011; Vardar et al. 2016; Özbey et al. 2021) 
and as distributed deformation. After 20 years of investigations, on-shore and off-shore, we still do not know where and when the next earthquake will strike. The next earthquake of $M>7$ may occur along the seismic gap on the MMF or along one less prominent fault of the NAF system with no, or sparce, historical seismicity.

After the success of the prediction of Stein et al. 1997, the common view was that assessing the probability of the next big one $(M>7.4)$ in the Sea of Marmara, comparable to the 1766 earthquake, was a reachable objective (e.g. Par- sons et al. 2000; Parsons et al. 2004; Pondard et al. 2007). In 2000, for instance, Parsons et al. found "a $62 \pm 15 \%$ prob- ability (one standard deviation) of strong shaking during the next 30 years and $32 \pm 12 \%$ during the next decade". Today, the probability of an earthquake of $M>7$ occurring along the MMF is estimated to be the highest for the central or east- ern part of the Sea of Marmara (e.g. Bulut et al. 2019), and the "possibility of a westerninitiated, super-shear rupture propagating eastward, the worst scenario for the Istanbul region, cannot be ruled out" (quote from Aochi and Ulrich 2015). When the September, 26th 2019, earthquake of mag- nitude 5.4 occurred in the MMF principal shear zone near the western end of the Istanbul-Sılıvrı segment (Karabulut et al. 2020), 20 years after the Izmir earthquake, nobody was able to tell whether this event was the precursor of a larger earthquake of $M>7$. The despair that then affected the scientific community reflects that we still have much to learn and many scientific questions to address:

- What is the role of the deep crustal structure on the seismogenic behavior of active faults?

- What is the role of asymmetry in crustal elastic properties north and south of the fault? Does it for instance explain the low, or no, interseismic loading in the Istanbul area at about $10 \mathrm{~km}$ distance from the fault (Ergintav et al. 2014)?

- What is the real significance of "creeping" along active faults? (Cetin et al. 2014)

- How much stress is released or transferred to adjacent segments by earthquakes of intermediate magnitude?

- What is the contribution to creeping that can be, respec- tively, ascribed to the presence of: (i) serpentinite crustal bodies at depth as below the IsmiztpaŞa (e.g. Cetin et al. 2020)? (ii) soft sediment cover (e.g. Yamamoto et al. 2019)? (iii) high fluid pressure (Géli et al. 2018)?

- Are there slow-slip events-yet undetected-along the MMF?

The Sea of Marmara has also been shown to be a unique, natural laboratory to improve our understanding of the rela- tionships between fault activity, seismicity, fluid migration and ecosystems at a major, transform plate boundary (e.g. Ruffine et al. 2018a; Hensen et al. 2019):
- Are there changes in the fault-fluid properties during the earthquake cycle that could be detectable from the seafloor?

- Can fluids transformations produce archives of past seismicity along the MMF fault segments?

Continuous, long-term time series are cruelly miss-ing to address some of the fundamental questions listed above. Implementing multi-parameter seafloor observatories (including seismology, geodesy and sensors on fluid properties) is a long-term enterprise, that demands sustained efforts, adapted facilities, dedicated manpower, which all require political and financial support. We are only in the middle of the way and we must go on. What is the most needed today, is to unite forces, to build a project supported by all institutions in Turkey and by the international scien- tific community.

Acknowledgements We particularly thank here Celal Şengör and Xavier Le Pichon for initiating the Turkish-French collaboration in marine geoscience and for their scientific mentoring since 1999; Naci Görür, for his decisive role as TUBITAK's general coordina- tor of marine geological and geophysical studies in Turkish seas; and all PI's of the different cruises conducted within the collaboration: Emin Demirbağ, Alfred Hirn, Satish Singh, Tuncay Taymaz, Rolando Armijo, Jacques Malavieille, Laurent Labeyrie, Bernard Mercier de Lépinay, Gilles Lericolais, Gilles Delaygue, Livio Ruffine, with special thoughts to the late, inspiring, Aykut Barka, who passed away in 2002

-a few months before co-chiefing the MarmaraScarps cruise, along with Rolando and Jacques. We also thank the general commander of SHOD, who offered repeated support during every single cruise conducted in the Sea of Marmara; the scientific attachés at the French embassy in Ankara, -particularly Mrs Bonnafous Boucher for the Marsite Cruise; Nurcan Meral Özel (KOERI), coordinator of the EU-Funded Marsite Programme; Ziya Çakır co-PI of the Maregami Project. Finally, we acknowledge all active contributors, e. g. Stéphanie Dupré, Céline Grall, Sinan Özeren, Gülsen Uçarkus, Kadir Eriş, Caner Imren, Cengiz Zabcı, Günay Çifci, Hakan Şarıtaş; as well as Cemil Gürbüz, Doğan Kalafat, Mustafa Comoğlu, Hayrullah Karabulut, Mustafa Aktar, Semih Ergintav, for their support; Luca Gasperini, who repeatedly offered opportunities for French and Turkish groups to embark on board the Italian R/V Urania in 2009, 2011 and 2013; Paolo Favali and his group from INGV who helped develop multi-disciplinary sea-floor observatories initiatives in the Sea of Marmara; Loïc Dussud and Jean-Romain Lagadec, contributors of the Maregami concept; and all those people who contributed to the success of the Turkish-French collaboration in marine geosciences, but are too many to be listed here individually.

\section{References}

Abalain K (2018) IFREMER MAREGAMI Buoy definition. Technical Report No. S44478-SEN-STR-REP-001. https://archimer.ifrem er.fr/doc/00458/57000/

Akbayram K, Sorlien CC, Okay Al (2016) Evidence for a minimum $52 \pm$ $1 \mathrm{~km}$ of total offset along the northern branch of the North Anatolian Fault in northwest Turkey. Tectonophysics 668669:35-41. https://doi.org/10.1016/j.tecto.2015.11.026

Aksu AE, Hiscott RN, Yaşar D (1999) Oscillating Quaternary water levels of the Marmara Sea and vigorous outflow into the Aegean 
Sea from the Marmara Sea Black Sea drainage corridor. Mar Geol 153:275-302. https://doi.org/10.1016/S0025-3227(98) 00078-4

Aksu AA, Calon TJ, Hiscott RN, Yaşar D (2000) Anatomy of the North Anatolian Fault Zone in the Marmara Sea, western Turkey: extensional basins above a continental transform, GSA Today, pp https://www.geosociety.org/gsatoday/archive/10/6/pdf/ gt0006.pdf

Aksu AE, Hiscott RN, Kaminski MA, Mudie PJ, Gillespie H, Abrajano T, Yaşar D (2002) Last glacial-Holocene paleoceanography of the Black Sea and Marmara Sea: stable isotopic, foraminiferal and coccolith evidence. Mar Geol 190:119-149

Aloisi G, Soulet G, Henry P, Walmann K, Sauvestre R, Vallet-Coulomb C, Lécuyer C, Bard E (2015) Freshening of the Marmara Sea prior to its post-glacial reconnection to the Mediterranean Sea. Earth Plan Sci Lett 413:176-185. https://doi.org/10.1016/j.epsl. 2014.12.052

Alpar B (1999) Underwater signatures of the Kocaeli earthquake (August 17th 1999). Turk J Mar Sci 5(3):111-130

Alpar B, Yaltirak C (2000) Tectonic setting of the eastern Marmara Sea. In: Görür N, Papadopoulos GA, Okay N (eds) Integration of earth science research on the Turkish and Greek 1999 Earth- quakes. NATO Science Series: IV: earth and environmental sci- ences, vol 9. Springer, Dordrecht, pp 35-46

Ambraseys NN (2002) The seismic activity of the Marmara Sea Region over the last 2000 years. Bull Seis Soc Am 92:1-18. https://doi. org/10.1785/0120000843

Ambraseys NN, Finkel C (1995) The seismicity of Turkey and adjacent areas; a historical review: 1500-1800. ErenYayıncılık, Istanbul Aochi $\mathrm{H}$, Ulrich T (2015) A probable earthquake scenario near istan- bu determined from dynamic simulations. Bull Seism Soc Am 105(3):1468-1475. https://doi.org/10.1785/0120140283

Armijo R, Meyer B, Hubert A, Barka A (1999) Westwards propagation of the North Anatolian Fault into the NorthAegean Timing and kinematics. https://doi.org/10.1130/0091-

7613(1999)027\%3c0267:WPOTNA\%3e2.3.CO;2

Armijo R, Meyer B, Navarro S, King G (2002) Slip partitioning in the Sea of Marmara pull-apart: a clue to propagation processes of the North Anatolian Fault. Terra Nova 14:80-86

Armijo R et al (2005) Submarine fault scarps in the Sea of Marmara pull-apart (North Anatolian Fault): implications for seismic hazard in Istanbul. Geochem Geophys Geosyst. https://doi.org/10. 1029/2004GC000896Q06009

Barka AA (1981) Seismo-tectonic aspects of the North Anatolian Fault Zone. PhD Thesis, University of Bristol, p 335

Barka AA (1992) The North Anatolian Fault Zone. Ann Tectonicae 6:164-195

Barka AA (1996) Slip distribution along the North Anatolian fault associated with large earthquakes of the period 1939 to 1967. Bull Seism Soc Am 86:1238-1254

Barka AA (1999) The 17 August 1999 Izmit earthquake. Science 285:1858-1859.

https://doi.org/10.1126/science.285.5435.1858

Barka AA, Kadinsky-Cade K (1988) Strike-slip fault geometry in Tur- key and its infuence on earthquake activity. Tectonics 7:663-684 Bayrakci G, Laigle M, Bécel A, Hirn A et al (2013) 3-D sediment-base- ment tomography of the Northern Marmara trough by a dense OBS network at the nodes of a grid of controlled source profiles along the North Anatolian fault. Geophys J Int 194(3):13351357. https://doi.org/10.1093/gji/ggt211

Bayrakci G, Scalabrin C, Dupré S et al (2014) Acoustic monitoring of gas emissions from the sea floor. Part II: characterization of gas related processes in shallow sediments, based on the combined interpretation of acoustic and seismological datasets. Mar Geophys Res. https://doi.org/10.1007/s11001-014-9227-7
Bécel A, Laigle M, De Voogd B, Hirn A, Taymaz T et al (2009) Moho, crustal architecture and deep deformation under the North Mar- mara Trough from the SEISMARMARA Leg-1 offshoreonshore reflection-refraction survey. Tectonophysics 467:1-21. https:// doi.org/10.1016/j.tecto.2008.10.022

Bécel $A$, Laigle $M$, de Voogd $B$, Hirn A, Taymaz T, Yolsal-Cevikbilen $S$ Shimamura $H$ (2010) North Marmara Trough architecture of basin infill, basement and faults, from PSDM reflection and OBS refraction seismics. Tectonophysics 490:1-14. https://doi.org/10. 1016/j.tecto.2010.04.004

Beck C, Mercier de Lépinay B, Schneider J-L, Cremer, et al (2007) Late Quaternary co-seismic sedimentation in the Sea of Mar-mara's deep basins. Sed Geol 199(65-89):58. https://doi.org/10. 1016/j.sedgeo.2005.12.031

Beck C, Campos C, Eris KK, Çağatay N, de Lepinay BM, Jouanne F (2015) Estimation of successive coseismic vertical offsets using coeval sedimentary events - application to the southwestern limit of the Sea of Marmara's Central Basin (North Anatolian Fault). Nat Hazards Earth Syst Sci 15(2):247-259. https://doi.org/10.5194/nhess-15-247-2015

Bohnhoff M, Bulut F, Dresen G, Malin PE, Eken T, Aktar M (2013) An earthquake gap south of Istanbul. Nat Commun 4(1):1999. https://doi.org/10.1038/ncomms2999

Bohnhoff M, Wollin C, Domigall D, Küperkoch L, Martínez-Garzón P, Kwiatek G, Dresen G, Malin PE (2017) Repeating Mar- mara Sea earthquakes: indication for fault creep. Geophys J Int 210(1):332-339. https://doi.org/10.1093/gji/ggx169

Bompais X (2018) Etude préliminaire de la liaison entre les stations et les instruments distants. No. REM-RDT-SIIM 18-R003

Bourry C, Chazalon B, Charlou J-L, Donval J-P, Rufine L, Henry P, Géli $L$, Çagatay N, Inan S, Moreau M (2009) Free gas and gas hydrates from the Sea of Marmara Turkey: chemical and struc- tural characterization. Chem Geol. https://doi.org/10.1016/j. chemgeo.2009.03.007

Bulut F, Bohnhoff M, Ellsworth WL, Aktar M, Dresen G (2009) Microseismicity at the North Anatolian Fault in the Sea of Marmara offshore Istanbul, NW Turkey. J Geophys Res Solid Earth 114:1-16. https://doi.org/10.1029/2008JB006244

Bulut F, Aktug B, Yaltırak C et al (2019) Magnitudes of future large earthquakes near Istanbul quantified from 1500 years of historical earthquakes, present-day microseismicity and GPS slip rates. Tectonophysics 764:77-87. https://doi.org/10.1016/j. tecto.2019.05.005

Burnard P, Bourlange S, Henry P, Geli L, Tryon MD, Natalin B, Şengör AMC, Ozeren MS, Cagatay MN (2012) Constraints on fluid origins and migration velocities along the Marmara Main Fault (Sea of Marmara, Turkey) using helium isotopes. Earth Plan Sci Lett. https://doi.org/10.1016/j.epsl.2012.05.042

Çağatay MN, Uçarkuş G (2019) Morphotectonics of the Sea of Marmara: basins and highs on the North Anatolian continental transform plate boundary. In: Duarte J (ed) Transform plate boundaries and fracture zones. Elsevier. https://doi.org/10. 1016/B978-0-12-812064-4.00016-5

Çağatay MN, Algan O, Sakınç M, Eastoe CJ, Egesel L, Balkıs N, Ongan D, Caner H (1999) A mid-late Holocene sapropelic sediment unit from the southern Marmara Sea shelf and its palaeoceanographic significance. Quat Sci Rev 18:531-540

Çağatay MN, Görür N, Algan A, Eastoe CJ, Tchapalyga A, Ongan D, Kuhn T, Kuşcu i (2000) Late Glacial-Holocene palaeoceanography of the Sea of Marmara: timing of connections with the Mediterranean and the Black Sea. Mar Geol 167:191-206

Çağatay MN, Erel L, Bellucci LG, Polonia A, Gasperini L, Eriş KK, Sancar Ü, Biltekin D, Uçarkuş G, Ülgen UB, Damcı E (2012) Sedimentary earthquake records in the İzmit Gulf Sea 
of Marmara. Sediment Geol 282:347-359. https://doi.org/10. 1016/j.sedgeo.2012.10.001

Çağatay MN, Wulf S, Sancar Ü, Özmaral A, Vidal L, Henry P, Appelt O, Gasperini L (2015a) The tephra record from the Sea of Marmara for the last ca. $70 \mathrm{ka}$ and its palaeoceanographic implications. Mar Geol 361:96-110

Cagatay N, Géli L, Henry P, Gasperini L, Görür N, Gürbüz C, (2015b) Seafloor observations and observatory activities in the Sea of Marmara. In: Favali P, Beranzoli L, De Santis A (eds) Seafloor observatories. Springer Praxis Book, Springer Verlag, Berlin Heidelberg, pp 59-79, https://doi.org/10.1007/ 978-3-64211374-1 4

Çağatay MN, Y.Idız G, Bayon G, Ruffine L, Henry P (2018) Seafloor authigenic carbonate crusts along the submerged part of the North Anatolian Fault in the Sea of Marmara: Mineralogy, geochemistry, textures and genesis. Deep-Sea Res Part II. https:// doi.org/10.1016/j.dsr2.2017.09.003

Çağatay Erel E, Biltekin D, Uçarkuş U, Ülgen UB, Acar D, Özmaral Ö, Albut G (2013) Analyses and dating of sediment cores from the Sea of Marmara for past earthquake records (in Turk- ish with English abstract). Report, p 198, Funded by Turkish National Union of Geodesy and Geophysics (TNUGG), Proje No: TUJJBUDP-02-10

Carton H, Singh S, Hirn A, Bazin S, de Voogd B, Vigner A, Rocil- leau A, Cetin S, Oçakoğlu N, Karakoç F, Sevilkgen V (2007) Seismic imaging of the three-dimensional architecture of the Cinarcık Basin alongh the North Anatolian Fault. J Geophys Res 112:B06101. https://doi.org/10.1029/2006JB004548

Cetin E, Cakir Z, Meghraoui M, Ergintav S, Akoglu AM (2014) Extent and distribution of aseismic slip on the Ismetpaşa segment of the North Anatolian Fault (Turkey) from Persistent Scatterer InSAR. Geochem Geophys Geosyst 15:2883-2894. https://doi.org/10. 1002/2014GC005307

Chadwell D (2017) Update on GPS-acoustic measurements on the continental slope of the cascadia subduction zone. In: AGU Fall Meeting 2017, abstract \#T51E-0525

Chevalier N, Bouloubassi I, Birgel D, Crémière A, Taphanel M-H, Pierre $C$ (2011) Authigenic carbonates at cold seeps in the Mar- mara Sea (Turkey): a lipid biomarker and stable carbon and oxy- gen isotope investigation. Mar Geol 288:112-212. https://doi. org/10.1016/j.margeo.2011.08.005

Chevalier N, Bouloubassi I, Birgel D, Taphanel M-H, Lopez-Garcia P (2013) Microbial methane turnover at Marmara Sea cold seeps: a combined 16S rRNA and lipid biomarker investigation. Geobiology 11:55-71. https://doi.org/10.1111/gbi.12014

Crémière $A$, Pierre $C$, Valleron $M M$, Zitter T, Çağatay $M N$, Henry $P$ (2012) Methane-derived authigenic carbonates along the North Anatolian fault system in the Sea of Marmara (Turkey). Deep Sea Res I 66:114-130

Demirbağ E, Rangin C, Le Pichon X, Şengör C (2003) Investigation of the tectonics of the Main Marmara Fault, by means of deeptowed seismic data Tectonophysics 361:1-19. https://doi.org/10. 1016/S0040-1951(02)00535-8

Drab LH, Ferrari A, Schmidt S, Martinez P (2012) The earthquake sedimentary record in the western part of the Sea of Marmara Turkey. Nat Hazards Earth Syst Sci 12:1235-1254. https://doi. org/10.5194/nhess-12-2012

Dresen G, Malin PE (2017) Repeating Marmara Sea earthquakes: indication for fault creep. Geophys J Int 210:332-339. https://doi. org/10.1093/gji/ggx169

Dupré S, Scalabrin C, Grall C, Augustin J-M, Henry P et al (2015) Tectonic and sedimentary controls for widespread gas emissions in the Sea of Marmara, Results from systematic, ship-borne multibeam echosounder water column imageries. J Geophys Res 120-5:2891-2912. https://doi.org/10.1002/2014JB011617
Dupré S, Scalabrin C, Augustin J-M, Guérin C, Ogor A, Clouet H, Géli L (2018) Spatial distribution of gas emissions from the Sea of Marmara seafloor from 4 November 2009 to 14 December 2009. SEANOE database. https://doi.org/10.17882/54983

Embriaco D, Marinaro G, Frugoni F, Giovanetti G, Monna S, Etiope G et al (2014) Monitoring of gas and seismic energy release by multiparametric benthic observatory along the North Anatolian Fault in the Sea of Marmara (NW Turkey). Geophys J Int 196(2):850-866. https://doi.org/10.1093/gii/ggt436

Ergintav S, Reilinger R, Çakmak R, Floyd M, Çakir Z, Doğan U, King RW, McClusky S, Özener H (2014) Istanbul's earthquake hot spots: geodetic constraints on strain accumulation along faults in the Marmara seismic gap. Geophys Res Lett. https://doi.org/ 10.1002/2014GL060985

Ergün M, Özel E (1995) (1985), Structural relationship between the Sea of Marmara Basin and the North Anatolian Fault Zone, 1995. Terra Nova 7:278-288. https://doi.org/10.1111/j.1365-3121. 1995.tb00695.x

Eriş KK, Ryan WBF, Cağatay MN, Sancar U, Lericolais G, Menot G, Bard $E$ (2007) The timing and evolution of the post-glacial transgression across the Sea of Marmara shelf south of Istanbul. Mar Geol 243:57-76

Eriş KK, Ryan WBF, Çağatay MN, Lericolais G, Sancar Ü, Menot G, Bard E (2008) Reply to Comment on "The timing and evolu- tion of the post-glacial transgression across the Sea of Marmara shelf south of Istanbul" by Hiscott et al. Mar Geol 248:228-236. https://doi.org/10.1016/j.margeo.2008.04.005

Eriş KK, Cağatay MN, Beck CM, de Lepinay B, Corina C (2012) LatePleistocene to Holocene sedimentary fills of the Çınarcık Basin of the Sea of Marmara. Sed Geol 281:151-165

Flerit F, Armijo R, King GCP, Meyer B, Barka AA (2003) Slip partitioning in the Sea of Marmara pull-apart determined from GPS velocity vectors. Geophys J Int 154:1-7

Flerit F, Armijo R, King GCP, Meyer B (2004) The mechanical interac- tion between the propagating North Anatolian Fault and the back- arc extension in the Aegean. Earth Plan Sci Lett 224(34):347- 362. https://doi.org/10.1016/j.epsl.2004.05.028

Gasperini L, Polonia A, Bortoluzzi G, Henry P, Le Pichon X, Tryon M Cagatay MN, Géli L (2011) How far did the surface rupture of the 1999 Izmit earthquake reach in Sea of Marmara? Tectonics 30:TC1010. https://doi.org/10.1029/2010TC002726

Gasperini L, Polonia A, Çağatay MN (2018) Fluid flow, deformation rates and the submarine record of major earthquakes in the Sea of Marmara, along the North-Anatolian Fault system. Deep Sea Res Part II 153:4-16. https://doi.org/10.1016/j.dsr2.2018.03.004

Géli L, Henry P, Zitter T, Dupré S et al (2008) Gas emissions and active tectonics within the submerged section of the North Ana- tolian fault zone in the Sea of Marmara. Earth Plan Sci Lett 274:34-39. https://doi.org/10.1016/j.epsl.2008.06.047

Geli L, Henry P, Grall C, Tary J-B et al (2018) Gas and seismicity within the Istanbul seismic gap. Sci Rep 8(1):6819. https://doi. org/10.1038/s41598-018-23536-7

Görür N, Elbek S (2013) Tectonic events responsible for shaping the Sea of Marmara and its surrounding region. Geodyn Acta. https://doi.org/10.1080/09853111.2013.859346

Görür N, Çağatay MN, Sakınç M, Sümengen M, Sentürk K, Yaltırak C, Tchapalyga A (1997) Origin of the Sea of Marmara from Neogene to Quaternary paleogeographic Evolution of its frame. Int Geol Rev 39:342-352

Görür N, Papadopoulos GA, Okay N (2002) Integration of earth science research on the Turkish and Greek 1999 earthquakes, NATO Science Series, IV earth and environmental sciences, vol 9. Kluwer Academic Publishers, p 207

Grall C, Henry P, Tezcan D, de Lepinay BM, Bécel A, Géli L, Rudk- iewicz $J$-L, Zitter T, Harmegnies F (2012) Heat flow in the Sea of Marmara Central Basin: Possible implications for the tectonic 
evolution of the North Anatolian fault. Geology 40(1):3-6. https://doi.org/10.1130/G32192.1

Grall C, Henry P, Thomas Y, Westbrook GK, Cağatay MN, Marsset B, Saritas H, Çifçi G, Géli L (2013) Slip rate estimation along the western segment of the Main Marmara Fault over the last 405$490 \mathrm{ka}$ by correlating mass transport deposits. Tectonics 32:1587-1601. https://doi.org/10.1002/2012TC003255

Grall C, Dupré S, Guérin C, Normand A, Gaillot A, Fleury J, Henry P, (2018a) Processed AsterX AUV data from the Sea of Marmara: high-resolution bathymetry and seafloor backscatter images. https://doi.org/10.17882/55744

Grall C, Henry P, Dupré S, Géli L, Scalabrin C, Zitter TAC, Sengor AMC, Cagatay MN, Cifci G (2018b) Upward migration of gas in an active tectonic basin: An example from the sea of Marmara. Deep Sea Res Part II Top Stud Oceanogr 153:17-35. https://doi. org/10.1016/j.dsr2.2018.06.007

Guidoboni E, Comastri A (2005) Catalogue of Earthquakes and Tsunamis in the Mediterranean area from 11th to the 15th century. INGV-SGA, Bologna, p 1057

Guidoboni E, Comastri A, Traina G (1994) Catalogue of Ancient Earthquakes in the Mediterranean area up to 10 th century. INGSGA, Bologna, p 504

Gürbüz C, Kalafat D, Yılmazer M, Kekovalı K, Ögütçü Z, Günes Y, Kara M, Suvarıklı M (2009) Eş Zamanlı Deniz Dibi Gözlem- lerine Bir Örnek: Marmara Denizi, Deniz Dibi Gözlemevi (MDDG), Aktif Tektonik Arasstırma Grubu ATAG 13. Calıștayı Bildiri Özleri Kitapçığı (An Example of realtime Sea Bottom Observations: Marmara Sea, Sea Bottom Observatory (MSBO), Active Tectonics Research Group ATAG 13th Workshop Abstracts Book) s. 28, 8-11 Ekim 2009 Çanakkale (in Turkish)

Gürbüz C, Kalafat D, Yilmazer M, Tunç S, Guvercin S (2011) Location of Marmara Sea Earthquakes Using Marmara Sea Bottom Observatories (MSBO) and Land Stations, ORFEUS Coordination Workshop (Integrating Seafloor and land-based seismographic observations), Lisbon May 2011. http://orfeus-lisbon.ist.utl.pt/

Halbach P, Kusçu I, Kuhn T, Pekdeğer A, Seifert R (2000) Methane in sediments of the deep Marmara Sea and its relation to local tectonic structures: NATO Advanced Research Seminar: Integration of Earth Sciences Research on the 1999 Turkish and Greek Earthquakes and Needs for Future Cooperative Research Seminar Abstract Book p. 74-75, 14-17 May 2000, Istanbul

Halbach P, Kuşç I, Inthorn M, Kuhn T, Pekdeğer A, Seifert R (2002) Methane in Sediments of the Deep Marmara Sea and Its Relation to Local Tectonic Structures. In: Görür N, Papadopoulos GA, Okay N (eds) Integration of earth science research on the Turkish and Greek 1999 Earthquakes. NATO Science Series: IV: Earth and Environmental Sciences, vol 9. Springer, Dordrecht. https:// doi.org/10.1007/978-94-010-0383-4 6

Halbach P, Holzbecher E, Reichel T, Moche R (2004) Migration of the sulphate-methane reaction zone in marine sediments of the Sea of Marmara-can this mechanism be tectonically induced? Chem Geol

205:73-82. https://doi.org/10.1016/j.chemgeo.2003.12.013

Henry P, Şengör AMC, Çagatay MN, Marnaut Scientic Party (2007). Marnaut cruise https://archimer.ifremer.fr/doc/00398/50967/

Henry P, Grall C, Kende J, Viseur S, Özeren MS, Şengör AMC, Dupré S, Scalabrin C, Géli L (2018) A statistical approach to relation- ships between fluid emissions and faults: The Sea of Marmara case. Deep Sea Res Part II. https://doi.org/10.1016/j.dsr2.2018. 05.010

Hensen C, Duarte JC, Vannucchi P, Mazzini A et al (2019) Marine transform faults and fracture zones: a joint perspective integrat- ing seismicity, fluid flow and life. Front Earth $\mathrm{Sci}$ 7(39):29p. https://doi.org/10.3389/feart.2019.00039
Hergert T, Heidbach O (2010) Slip-rate variability and distributed deformation in the Marmara Sea fault system. Nat Geosci 3:132135. https://doi.org/10.1038/NGEO739

Hergert T, Heidbach O (2011) Geomechanical model of the Marmara Sea region -11 . 3D contemporary background stress field. Geophys J Int 185-3:1090-1102. https://doi.org/10.1111/j.1365246X.2011.04992.x

Hiscott RN, Aksu AE, Mudie PJ (2008) Comment on the timing and evolution of the post-glacial transgression across the Sea of Marmara shelf south of Istanbul by Eris et al. Mar Geol 243:57-76

Hubert-Ferrari A, Barka A, Jacques E, Nalbant S, Meyer B, Armijo R, Tapponnier P, King GP (2000) Seismic hazard in the Marmara Sea region following the 17 August 1999 Içzmit Earthquake. Nature 404:269-273

İmren C, Le Pichon X, Rangin C, Demirbağ E, Ecevitoğlu B, Görür N (2001) The North Anatolian Fault within the Sea of Marmara: a new interpretation based on multichannel seismic and multibeam bathymetry data. Earth Planet Sci Lett 186:143-158. https://doi.org/10.1016/S0012-821X(01)00241-2

Kalafat D, Gürbüz C, Yılmazer M, Kekovalı K, Öğütcü $Z$, Güneş $Y$,

Kara M Suvarıklı M (2009) Marmara Denizi, Deniz Taban

Gözlemevi Projesi (MDTGP)- The Sea of Marmara, Sea Bottom Observatory Project (MSBOP), International Earthquake Sympo-

sium, Abstracts Book p. 61, 17-19 August 2009, Kocaeli-Turkey Kalafat

D, Pinar A, Ozel NM, Gurbuz C, Yilmazer M (2012) Land Based and Ocean Bottom Monitoring of Seismic Activity of North Anatolian Fault and its Branches in Marmara Region, 33rd General Assembly of the European Seismological Commission, EGU General Assembly 2012, August 19-24, Moscow, Russia

Karabulut H, Güvercin SE, Eskiköy F, Konca O, Ergintav S (2020) The moderate size 2019 SeptemberMw 5.8 Silivri earthquake unveils the complexity of the Main Marmara Fault shear zone. Geophys $\mathrm{J}$ Int 224:377-388. https://doi.org/10.1093/gji/ggaa469

Karabulut $\mathrm{H}$, Schmittbuhl J, Özalaybey S, Lengliné $\mathrm{O}$, Kömeç-Mutlu A Durand V, Bouchon M, Daniel G, Bouin MP (2011) Evolution of the seismicity in the eastern Marmara Sea a decade before and after the 17 August 1999 Izmit earthquake. Tectonophys- ics 510(1-2):17-27. https://doi.org/10.1016/j.tecto.2011.07.009

Karabulut H, Paul A, Ergün TA, Hatzfeld D, Childs DM, Aktar M (2013) Long-wavelength undulations of the seismic Moho beneath the strongly stretched Western Anatolia. Geophys J Int 194:450464. https://doi.org/10.1093/gji/ggt100

Kendé J, Henry P, Bayrakci G, Özeren MS, Grall C (2017) Moho depth and crustal thinning in the Marmara Sea region from gravity data inversion. J Geophys Res 122:1381-1401. https://doi.org/ 10.1002/2015JB012735

Ketin I (1968) Relations between general tectonic features and the main earthquake regions in Turkey. Bull Miner Res Explor Inst Turk (MTA Bull) 71:63-67

Klein E, Duputel Z, Masson F, Yavasoglu H, Agram P (2017) Aseismic slip and seismogenic cou-pling in the Marmara Sea: what can we learn from onland Geodesy? Geophys Res Lett 44:3100-3108. https://doi.org/10.1002/2017GL072777

Kuşçu I, Halbach P, Inthorn M, Kuhn T, Pekdeğer A, Seifert R (2008) The R/V Meteor Cruise Leg M44/1 in February 1999 in the Sea of Marmara: the first multibeam bathymetric study and analysis of methane in sediment and water columns. Turk J Earth Sci 17:461-480

Lagadec J-R (2018) Cahier des Charges Fonctionnel pour l'étude de la bouée de surface de l'observatoire MAREGAMI. Rapport Ifremer No. REM-RDT/SIIM/18-R015. Archimer reference No. 57001, https://archimer.ifremer.fr/doc/00458/57001/

Laigle M, Bécel A, de Voogd B, Hirn A, Taymaz T, Ozalaybey S, the Members of the SEISMARMARA Leg1 (2008) A first deep seismic survey in the Sea of Marmara: whole crust and deep 
basins. Earth Planet Sci Lett 270:168-179. https://doi.org/10. 1016/j.epsl.2008.02.031

Lange D, Kopp H, Royer J-Y, Henry P, Cakir Z et al (2019) Inter- seismic strain build-up on the submarine North Anatolian Fault offshore Istanbul. Nat Commun. https://doi.org/10.1038/ s41467-01911016-z

Le Pichon X, Chamot-Rooke N, Lallemant S, Noomen R, Veis G (1995) Geodetic determination of the kinematics of central Greece with respect to Europe implications for eastern Mediter- ranean tectonics. J Geophys Res 100:12675-12690

Le Pichon X, Taymaz T, Şengor AMC (1999) The Marmara Fault and the future Istanbul earthquake. In: International Conference on the Kocaeli Earthquake, 17 August 1999, edited by M. Karaça and D. N. Ural. pp. 41-54, Istanbul Tech. Univ. Press House, Istanbul, Turkey

Le Pichon X, Sengör AMC, Demirbağ E, Rangin C, Imren C, Armijo R, Görür N, Çağatay NM, Mercier de Lepinay B, Meyer B, Saatçılar $\mathrm{R}$, Tok B (2001) The active main Marmara fault. Earth Planet Sci Lett 192:595-616. https://doi.org/10.1016/ S0012$821 \times(01) 00449-6$

Le Pichon X, Chamot-Rooke N, Rangin C, Şengör AMC (2003) The North Anatolian Fault in the Sea of Marmara. J Geophys Res 108(B4):2179. https://doi.org/10.1029/2002JB001862

Le Pichon X, Imren C, Rangin C, Şengör AMC, Siyako M (2014) The South Marmara Fault. Int J Earth Sci (Geol Rundsch) 103:219231. https://doi.org/10.1007/s00531-013-0950-0

Le Pichon X, Şengör AMC, Kende J, Henry P, Grall C, Karabu- lut $H$, Sengör AMC (2016) Propagation of a strike-slip plate boundary within an extensional environment: the westward propagation of the North Anatolian Fault. Can J Earth Sci. 53(11):1416-1439. https://doi.org/10.1139/cjes-2015-0129

Lindsey NJ, Martin ER, Dreger DS, Freifeld B et al (2017) Fiber-optic network observations of earthquake wavefields. Geophys Res Let 44. https://doi.org/10.1002/2017GL075722

McHugh CMG, Seeber L, Cormier M-H, Dutton J, Çağatay MN, Polonia A, Ryan WBF, Görür N (2006) Submarine earthquake geology along the North Anatolian Fault in the Marmara Sea, Turkey: a model for transform basin sedimentation. Earth Plan Sci Lett 248:661-684. https://doi.org/10.1016/j.epsl.2006.05. 038

McHugh CMG, Braudy N, Çağatay MN, Sorlien C, Cormier M-H, Seeber L, Henry P (2014) Seafloor fault ruptures along the North Anatolia Fault in the Marmara Sea, Turkey: link with the adjacent basin turbidite record. Mar Geol 353(1):65-83. https://doi.org/10.1016/j.margeo.2014.03.005

Meade BJ, Hager BH, McClusky SC, Reilinger R, Ergintav S, Lenk O, Barka AA, Özener H (2002) Estimates of seismic poten- tial in the Marmara Sea region from block models of secular deformation constrained by Global Positioning System meas- urements. Bull Seismol Soc Am 92:208-215. https://doi.org/ 10.1785/0120000837

Müller UC, Pross J, Tzedakis P, Gambled C, Kotthoff U et al (2011) The role of climate in the spread of modern humans into Europe. Quater Sci $\quad$ Rev 30:273-279. https://doi.org/10.1016/j.quascirev. 2010.11.016

Meghraoui M, Aksoy ME, Aksyüz HS, Ferry M, Dikbas A, Altunel E (2012) Paleoseismology of the North Anatolian Fault at Gü zelköy (Ganos segment, Turkey): Size and recurrence time of earthquake ruptures west of the Sea of Marmara. Geochem Geophys Geosyst 13(4):Q04005. https:// doi. org/ 10. 1029/ 2011GC003960

Nowaczyk NR, Arz HW, Frank U, Kind J, Plessen B (2012) Dynam- ics of the Laschamp geomagnetic excursion from Black Sea sediments. Earth Plan Sci Let 351-352:54-69
Okay S, Aydemir S (2016) Control of active faults and sea level changes on the distribution of shallow gas accumulations and gasrelated seismic structures along the central branch of the North Anatolian Fault, southern Marmara shelf Turkey. Geodin Acta. https://doi.org/10.1080/09853111.2016.1183445

Okay Al, Demirbağ E, Kurt H, Okay N, Kuşçu I (1999) An active, deep marine strike-slip basin along the North Anatolian Fault in Turkey. Tectonics 18:129-147. https://doi.org/10.1029/ 1998TC900017

Okay Al, Kaşlilar-Özcan A, Imren C, Boztepe-Güney A, Demirbağ E, Kuşçu I (2000) Active faults end evolving strike-slip basins in the Marmara Sea, northwest Turkey: a multichannel seismic reflection study. Tectonophysics 321:189-218. https://doi.org/ 10.1016/S0040-1951(00)00046-9

Ondréas H, Olu K, Dupré S, Scalabrin C, Alix A-S, Garrocq C, Ruff- ine L (2020) Geological and biological diversity of seeps in the Sea of Marmara. Deep Sea Res Part I 161:103287. https:// doi.org/10.1016/j.dsr.2020.103287

Örgülü G (2011) Seismicity and source parameters for small-scale earthqukes along the splays of the North Anatolian Fault (NAF) in the Marmara Sea. Geophys J Int 184(1):385-404

Özel E (1992) Marmara Denizinin neotektonik yapısının jeofisik yöntemlerle incelenmesi. PhD Thesis, Dokuz Eylüll Universi- tesi, Izmir

Özel NM, Necmioglu O, Ergintav S, Özel O, Italiano F et al. (2017) MARSite-MARMARA SUPERSITE: accomplishments and Outlook. In: EGU General Assembly 2017, Apr 2017, Vienne, Austria. Geophys. Res. Abs., pp. EGU2017-18891

Özbey V, Özeren S, Henry P, Klein E, Galgana, Karabulut H, Lange D, McCaffrey R (2021) Kinematics of the Marmara Region: a fusion of continuum and block models. Med Geosc Rev. https:// doi.org/10.1007/s42990-021-00051-y

Palabıyık Y, Ozdemir A, Karataş A (2020) The safloor indications for hydrocarbon potential of the Marmara Sea Basin (Northwestern Turkey) and proposed exploration zones along with some drilling locations, International Black Sea Coastline Countries Symposium - IV, 5-6 May 2020, Giresun, Turkey, https://www.resea rchgate.net/publication/341281113

Parke JR, Minshull TA, Anderson A, White RS, McKenzie D, Kuscu I, Bull J, Görür N, Şengör AMC (1999) Active faults in the Sea of Marmara, western Turkey, imaged by seismic reflection profiles. Terra Nova 11:223-227

Parke JR, Minshull TA, Anderson A, White RS, McKenzie D, Kuscu I, Bul J, Görür N, Sengör AMC (2002) Interaction between fault- ing and sedimentation in the Sea of Marmara, western Turkey. J Geophys Res. https://doi.org/10.1029/2001JB000450

Parke JR, Minshull TA, Anderson A, White RS, McKenzie D, Kuscu I, Bull J, Görür N, Sengör AMC (2003) The Sea of Marmara: a twodimensional seismic reflection profile data archive. Geo- chem Geophys Geosyst 4(10):1084. https://doi.org/10.1029/ 2002GC000493

Parsons T (2004) Recalculated probability of M_7 earthquakes beneath the Sea of Marmara, Turkey. J Geophys Res 109:B05304. https:// doi.org/10.1029/2003JB002667

Parsons T, Toda S, Stein RS, Barka A, Dieterich JH (2000) Heightened odds of large earthquakes near Istanbul: an interaction-based probability calculation. Science 288:661-665

Pinar N (1943) Marmara Denizi Havzasinin Sismik Jeoloji ve Meteorolojisi, PhD Thesis, Institut de Physique Générale de l'Université d'Istanbul, Kenan Matbaasi, Istanbul, p 64

Polonia A et al (2002) Exploring submarine earthquake geology in the Marmara Sea. Eos 83:229-236. https://doi.org/10.1029/2002E 0000158

Polonia A, Gasperini L, Amorosi A, Bonatti E, Çağatay N, Capo- tondi L, Cormier M-H, Gorur N, McHugh C, Seeber L (2004) 
Holocene slip rate of the North-Anatolian Fault beneath the Sea of Marmara. Earth Planet Sci Lett 227:411-426. https://doi.org/ 10.1016/j.epsl.2004.07.042

Pondard N, Armijo R, King GCP, Meyer B, Flérit F (2007) Fault interactions in the Sea of Marmara pull-apart (North Anatolian Fault): earthquake clustering and propagating earthquake sequences. Geophys J Int 171:1185-1197. https://doi.org/10.1111/j.1365246X.2007.03580.x

Rangin C, Demirbağ E, Caner I, Crusson A, Normand A, Le Drezen E, Le Bot A (2001) Marine atlas of the Sea of Marmara (Turkey). Data collected on board R. V Le Suroît, September 2000, https:// archimer.ifremer.fr/doc/00279/39006/

Rangin C, Le Pichon X, Demirbağ E, Imren C (2004) Strain localiza- tion in the Sea of Marmara: propagation of the North Anatolian Fault in a now inactive pull-apart. Tectonics 13(TC2014):1-18. https://doi.org/10.1029/2002TC001437

Reilinger R et al (1997) Global Positioning System measurements of present-day crustal movements in the Arabia-Africa-Eurasia plate collision zone. J Geophys Res 102:9983-9999. https://doi. org/10.1029/96JB03736

Reilinger R, McClusky S, Vernant P, Lawrence S et al (2006) GPS constraints on continental deformation in the Africa-Arabia-Eurasia continental collision zone and implications for the dynamics of plate interactions. J Geophys Res 111(B5):B05411. https://doi. org/10.1029/2005JB004051

Reilinger R, McClusky S, Paradissis Ergintav S, Vernant P (2010) Geodetic constraints on the tectonic evolution of the Aegean region and strain accumulation along the Hellenic subduction zone, Tectonophysics 488:22-30. https://doi.org/10.1016/j.tecto. 2009.05.027

Ritt B, Duperron S, Lorion J, Cassandre SL, Sarrazin J (2010) Integrative study of a new cold-seep mussel (Mollusca: Bivalvia) associated with chemosynthetic symbionts in the Marmara Sea. Deep-Sea Res 67(2012):121-132. https://doi.org/10.1016/j.dsr. 2012.05.009

Ruffine L, Fandino O, Etoubleau J, Chéron S, Donval JP, Germain Y, Ponzevera E, Guyader V, Dennielou B, Etiope G, Gasperini L, Bortoluzzi G, Henry P, Grall C, Çagatay MN, Charlou J-L, Géli L (2012) Geochemical dynamics of the natural-gas hydrate system in the Sea of Marmara offshore Turkey. Adv Nat Gas Technol. https://doi.org/10.5772/36343

Ruffine L, Germain Y, Polonia A, De Prunele A, Croguennec C et al (2015) Pore water geochemistry at two seismogenic areas in the Sea of Marmara. Geochem Geophys Geosyst 16(7):2038-2057. https://doi.org/10.1002/2015GC005798

Ruffine L, Donval J-P, Croguennec C, Burnard P et al (2018) Corrigendum to Multiple gas reservoirs are responsible for the gas emissions along the Marmara fault network. Deep Sea Res Part II: Top Stud Oceanogr 153:48-60. https://doi.org/10.1016/j.dsr2. 2017.11.011

Ruffine L, Cagatay MN, Géli L (2018a) Fluids and processes at the seismically active fault zone in the Sea of Marmara. Deep-Sea Res Part II-Top Stud Oceanogr 153:1-3. https://doi.org/10. 1016/j.dsr2.2018.09.011

Ruffine L, Donval J-P, Croguennec C, Burnard P et al (2018b) Mul- tiple gas reservoirs are responsible for the gas emissions along the Marmara fault network. Deep Sea Res Part II 153:145-149. https://doi.org/10.1016/j.dsr2.2018.12.002

Ruhl H, André M, Beranzoli L, Cagatay N, Colaço et al (2011) Societal need for improved understanding of climate change, anthropogenic impacts, and geo-hazard warning drive development of ocean observatories in European Seas. Prog Oceanogr 91-1:1-33

Sakic P, Piété H, Ballu V, Royer J-Y, Kopp H, Lange D et al (2016) No significant steady state surface creep along the north Anatolian fault offshore Istanbul: Results of 6 months of seafloor acoustic ranging. Geophys Res Let 43:6817-6825. https://doi.org/10. 1002/2016GL069600

Şarıtaş H, Çifçi G, Géli L et al (2018) Gas occurrence and shallow conduit systems in the Western Sea of Marmara: a review and new acoustic evidence. Geo-Mar Lett 38:385-402. https://doi. org/10.1007/s00367-018-0547-5

Sato T, Kasahara J, Taymaz T, Ito M, Kamimura A, Hayakawa T, Tan O (2004) A study of microearthquake seismicity and focal mechanisms within the Sea of Marmara (NW Turkey) using oceanbottom seismometers (OBS). Tectonophysics 391:303-314

Schmittbuhl J, Karabulut H, Lengliné O, Bouchon M (2015) Seismic- ity distribution and locking depth along the main Marmara fault Turkey. Geochem Geophys Geosyst 17:954-965. https://doi.org/ 10.1002/2015GC006120

Schmittbuhl J, Karabulut H, Lengliné O, Bouchon M (2016) Longlasting seismic repeaters in the Central Basin of the main Marmara fault. Geophys Res Lett 43:9527-9534. https://doi.org/10. 1002/2016GL070505

Seeber L, Emre O, Cormier M-H, Sorlien CC, McHugh C, Polonia A, Ozer $\mathrm{N}$, Cagatay N, The team of the $2000 \mathrm{R} / \mathrm{V}$ Urania Cruise in the Marmara Sea (2004) Uplift and subsidence from oblique slip: the Ganos-Marmara bend of the North Anatolian Transform, western Turkey. Tectonophysics 391(1-4):239-258. https://doi. org/10.1016/j.tecto.2004.07.015

Seeber L, Cormier MH, McHugh C, Emre O, Polonia A, Sorlien C (2006) Rapid subsidence and sedimentation from oblique slip near a bend on the North Anatolian transform fault in the Mar- mara Sea Turkey. Geology 34(11):933-936

Şengör AMC (1979) The North Anatolian transform fault: its age, onset and tectonic significance. J Geol Soc Lond 136:269-282

Şengör AMC, Görür N (1985) Strike-slip faulting and related basin formation in zones of tectonic escape: Turkey as a case study. In: Biddle KT, Blick NC (eds) Strike-slip deformation, basin formation and sedimentation 37. Soc. Econ. Paleon. Mine. Spec. Publication, pp 227-264

Şengör AMC, Tüysüz O, İmren C, Sakınç M, Eyidŏgan H, Görür G, Le Pichon X, Rangin C (2005) The North anatolian fault: a new look. Ann Rev Earth Planet Sci 33:37-112. https://doi.org/10. 1146/annurev.earth.32.101802.120415

Şengör AMC, Grall C, İmren C, Le Pichon X, Grür N, Henry P, Karab- ulut $H$, Siyako M (2014) The geometry of the North Anatolian transform fault in the Sea of Marmara and its temporal evolution: implications for the development of intracontinental transform faults. Can J Earth Sci 51(3):222-242. https://doi.org/10.1139/ cjes-2013-0160

Sladen A, Rivet D, Ampuero J-P, De Barros L, Hello Y, Calbris G, Lamar $P$ (2020) Distributed sensing of earthquakes and ocean- solid Earth interactions on seafloor telecom cables. Nature Com- mun 10:5777. https://doi.org/10.1038/s41467-019-13793-z

Smith A, Taymaz T, Oktay F, Yüce H, Alpar B, Başaran H, Jackson J, Kara S, Simsek M (1995) High-resolution seismic profiling in the Sea of Marmara (northwest Turkey): late quaternary sedimen- tation and sea-level changes. Geol Soc Am Bull 107:923-936. https://doi.org/10.1130/0016-7606(1995)107\%3c0923:HRSPIT\% 3e2.3.CO;2

Sorlien CC, Akhun SD, Seeber L, Steckler, et al (2012) Uniform basin growth over the last 500ka, North Anatolian Fault Marmara Sea Turkey. Tectonophysics 518-521:1-16. https://doi.org/10.1016/j. tecto.2011.10.006

Stanley DJ, Blanpied C (1980) Late Quaternary water exchange between the eastern Mediterranean and the Black Sea. Nature 285:537-541

Stein R, Barka AA, Dieterich JH (1997) Progressive failure on the North Anatolian fault since 1939 by earthquake stress trigger- ing. Geophys J Int 128:594-604. https://doi.org/10.1111/j.1365246X.1997.tb05321.x 
Tarancıoğlu A, Özalaybey S, Kocaoğlu AH (2020) Three-dimensional seismic tomographic imaging beneath the Sea of Marmara: evidence for locked and creeping sections of the Main Marmara Fault. Geophys J Int 223:1172-1187. https://doi.org/10.1093/ gji/ggaa389

Tary JB, Géli L, Henry P, Guennou C, Sultan N, Çagatay N, Vidal I (2012) Microevents produced by gas migration and expulsion at the seabed: a study based on sea bottom recordings from the Sea of Marmara. Geophys J Int. https://doi.org/10.1111/j.1365-246X. 2012.05533.x

Teichert BMA, Chevalier N, Gussone N, Bayon G, Ponzevera E, Ruff- ine L, Strauss H (2018) Sulfate-dependent anaerobic oxidation of methane at a highly dynamicbubbling site in the Eastern Sea of Marmara (Çinarcik Basin). Deep-Sea Res Part II: Top Stud Oceanogr https://doi.org/10.1016/j.dsr2.2017.11.014

Thomas Y, Marsset B, Westbrook GK, Grall C, Géli L, Henry P, Cifçi G, Rochat A, Saritas H (2012) Contribution of high-resolution 3D seismic near-seafloor imaging to reservoir scale studies: application to the active north Anatolian Fault Sea of Marmara. Near Surf Geophys 10:291-301. https://doi.org/10.3997/18730604.2012019

Töksöz MN, Shakal AF, Michael AJ (1979) Space-time migration of earthquakes along the North Anatolian fault zone and seismic gaps. PAGEOPH 117:1258-1270. https://doi.org/10.1007/BF008 76218

Tryon MD, Henry P, Çagatay MN, Zitter T, Géli L, Gasperini L, Bur- nard $P$, Bourlange S, Grall C (2010) Pore fluid in the North Ana- tolian Fault in the Sea of Marmara: a diversity of sources and processes. Geochem Geophys Geosyst. https://doi.org/10.1029/2010GC003177

Tryon M, Henry P, Hilton DR (2012) Quantifying submarine fluid seep activity along the North Anatolian Fault Zone in the Sea of Marmara. Mar Geol 315-318:15-18. https://doi.org/10.1016/j. margeo.2012.05.004

Tsang-Hin-Sun E, Batsi E, Klingelhoefer K, Géli L (2019) Spatial and temporal dynamics of gas-related processes in the Sea of Marmara monitored with ocean bottom seismometers. Geophys $J$ Int 216:1989-2003. https://doi.org/10.1093/gji/ggy535

Uçarkuş G (2010) Active faulting and earthquake scarps along the North Anatolian fault in the Sea of Marmara. Ph.D. Thesis, Istanbul Technical University, Eurasia Institute of Earth Sciences, $\mathrm{p} 178$

Uchida N, Kalafat D, Pinar A, Yamamoto (2019) Repeating earthquakes and interplate coupling along the western part of the North Anatolian Fault. Tectonophysics. https://doi.org/10.1016/j. tecto.2019.228185

Valsecchi V, Sánchez-Goñi MF, Londeix L (2012) Vegetation dynam- ics in the Northeastern Mediterranean region during the past
23,000 year: insights from a new pollen record from the Sea of Marmara. Clim Past 8:1941-1956. https://doi.org/10.5194/cp8-1941-2012

Vardar D, Alpar B (2016) High-resolution seismic characterization of shallow gas accumulations in the southern shelf of Marmara Sea. Turkey, Acta Geophys 64(3):589-609. https://doi.org/10.1515/ acgeo-2015-0059

Vidal L, Ménot G, Joly C, Bruneton H, Rostek F, Çağatay MN, Major C, Bard E (2010) Hydrology in the Sea of Marmara during the last 23 ka: Implications for timing of Black Sea connections and sapropel deposition. Paleoceanography 25(PA1205):1-16

Wong HK, Lüdmann E, Uluğ TA, Görür N (1995) The Sea of Marmara: a boundary sea in an escape tectonic regime. Tectonophysics 244:231-250. https://doi.org/10.1016/0040-1951(94)00245-5

Yakupoğlu N, Uçarkuş G, Eriş KK, Henry P, Cağatay MN (2019) Sedimentological and geochemical evidence for seismoturbidite generation in the Kumburgaz Basin, Sea of Marmara: Implica- tions for earthquake recurrence along the Central High Segment of the North Anatolian Fault. Sed Geol 380(2019):31-44. doi.org/10.1016/j.sedgeo.2018.11.002

Yaltirak C (2002) Tectonic evolution of the Marmara Sea and its surrounding. Mar Geol 190(1-2):493-529. https://doi.org/10.1016/ S0025-3227(02)00360-2

Yamamoto R, Kido M, Ohta Y, Takahashi N, Yamamoto Y, Pinar A et a (2019) Seafloor geodesy revealed partial creep of the north Anatolian fault submerged in the sea of Marmara. Geophys Res Lett 46:1268-1275. https://doi.org/10.1029/2018GL080984

Zabci C (2019) Spatio-temporal behaviour of continental transform faults: implica-tions from the late Quaternary slip history of the North Anatolian Fault, Turkey. Can J Earth Sci 56(11):12181238. https://doi.org/10.1139/cjes-2018-0308

Zitter TAC, Henry P, Aloisi G, Delaygue G, Çağatay MN, Mercier de Lepinay B, Al-Samir MF, Fornacciari M, Pekdeger A, Wallmann K Lericolais G (2008) Cold seeps along the main Marmara fault in the Sea of Marmara (Turkey). Deep Sea Res Part I 55:552-557

Zitter TAC, Grall C, Henry P, Özeren MS, Çağatay MN, Şengör AMC, Gasperini L, de Lépinay BM, Géli L (2012) Distribution, morphology and triggers of submarine mass wasting in the Sea of Marmara. Mar https://doi.org/10.1016/j.margeo.2012.09. 002
Geol. 